NBER WORKING PAPER SERIES

THE CONTINENTAL DOLLAR:

INITIAL DESIGN, IDEAL PERFORMANCE, AND THE CREDIBILITY OF CONGRESSIONAL COMMITMENT

Farley Grubb

Working Paper 17276

http://www.nber.org/papers/w17276

\author{
NATIONAL BUREAU OF ECONOMIC RESEARCH \\ 1050 Massachusetts Avenue \\ Cambridge, MA 02138 \\ August 2011
}

Preliminary versions were presented at Queens University, Kingston, Canada, 2010; University of Cambridge, Cambridge, UK, 2010; the National Bureau of Economic Research, Cambridge, MA, 2011; the annual meeting of the Economic History Association, Boston, MA, 2011; and the University of Delaware, Newark, DE, 2011. The author thanks the participants for their comments. Research assistance by John Bockrath, Jiaxing Jiang, and Zachary Rose, and editorial assistance by Tracy McQueen, are gratefully acknowledged. The views expressed herein are those of the author and do not necessarily reflect the views of the National Bureau of Economic Research.

NBER working papers are circulated for discussion and comment purposes. They have not been peerreviewed or been subject to the review by the NBER Board of Directors that accompanies official NBER publications.

(C) 2011 by Farley Grubb. All rights reserved. Short sections of text, not to exceed two paragraphs, may be quoted without explicit permission provided that full credit, including $(\subset$ notice, is given to the source. 
The Continental Dollar: Initial Design, Ideal Performance, and the Credibility of Congressional

Commitment

Farley Grubb

NBER Working Paper No. 17276

August 2011, Revised February 2013

JEL No. E42,E52,G12,G18,H11,H56,H6,H71,N11,N21,N41

\begin{abstract}
An alternative history of the Continental dollar is constructed from original sources and tested against evidence on prices and exchange rates. The Continental dollar was a zero-interest bearer bond, not a pure fiat currency. The public was promised redemption at face value in specie at fixed future dates. When time-discounting (rational bond pricing) is separated from depreciation, little depreciation occurred before 1779. In 1779, and again in 1780, Congress passed ex post facto laws altering Continental-dollar maturity dates. Because these new dates were not fiscally feasible, Congress' commitment to the Continental dollar lost credibility. Depreciation and collapse followed shortly thereafter.
\end{abstract}

\author{
Farley Grubb \\ University of Delaware \\ Economics Department \\ Newark, DE 19716 \\ and NBER \\ grubbf@udel.edu
}




\title{
The Continental Dollar: Initial Design, Ideal Performance, and the Credibility of Congressional Commitment
}

\author{
Farley Grubb ${ }^{1}$
}

An alternative history of the Continental dollar is constructed from original sources and tested against evidence on prices and exchange rates. The Continental dollar was a zerointerest bearer bond, not a pure fiat currency. The public was promised redemption at face value in specie at fixed future dates. When time-discounting (rational bond pricing) is separated from depreciation, little depreciation occurred before 1779. In 1779, and again in 1780, Congress passed ex post facto laws altering Continental-dollar maturity dates. Because these new dates were not fiscally feasible, Congress' commitment to the Continental dollar lost credibility. Depreciation and collapse followed shortly thereafter.

"The Continental Currency is the great Pillar, which Supports our Cause, and if that Suffers in its Credit, the Cause must Suffer: if that fails the Cause must fail."

John Adams to Samuel Cooper, 10 July $1776^{2}$

The United States Congress financed the War for Independence (1775-83) by issuing paper money—the Continental dollar. From 1775 through 1779, new emissions totaled \$200 million in face value and accounted for 77 percent of congressional spending. No new emissions occurred after November $1779 .^{3}$ Traditional historiography treats the Continental dollar as a pure fiat currency. As outstanding emissions accumulated, the Continental dollar depreciated and prices rose. In 1781, having lost all its value and run its course as an inflation tax, it was abandoned. "Not worth a Continental” became a common derogatory phrase. ${ }^{4}$

\footnotetext{
${ }^{1}$ Professor of Economics and Research Associate at the National Bureau of Economic Research, Economics Department, University of Delaware, Newark, DE 19716 USA. Email: grubbf@udel.edu. Webpage: http://www.lerner.udel.edu/faculty-staff/faculty/farley-grubb. Preliminary versions were presented at Queens University, Kingston, Canada, 2010; University of Cambridge, Cambridge, UK, 2010; the National Bureau of Economic Research, Cambridge, MA, 2011; the annual meeting of the Economic History Association, Boston, MA, 2011; and the University of Delaware, Newark, DE, 2011. The author thanks the participants for their comments. Research assistance by John Bockrath, Jiaxing Jiang, and Zachary Rose, and editorial assistance by Tracy McQueen, are gratefully acknowledged.

${ }^{2}$ Smith (1979, v. 4, p. 423).

${ }^{3}$ Grubb (2008; 2011, pp. 270-6; 2012a); Journals of the Continental Congress [JCC hereafter] (v. 15, pp. 1052-3).

${ }^{4}$ Baack (2001, 2008); Bolles (1969); Breck (1843); Bronson (1865); Bullock (1895, 1900); Calomiris (1988); Ferguson (1961); Fowler (2011, pp. 18, 23-4, 27); Gouge (1833); Harlow (1929); Hepburn (1967); Lint (1996, v. 9, pp. 427-96); Oberg (1992, v. 29, pp. 354-6); Perkins (1994); Phillips (1866); Ratchford (1941); Smith (1990, v. 17, pp. 149-50); Sumner (1968).
} 
At the 1787 Constitutional Convention the founding fathers used this experience to justify transforming governmental monetary powers in the new U.S. Constitution. On 16 August, the Convention voted to remove the power to emit paper money from the list of constitutional powers granted to Congress. Congress had had this power under the Articles of Confederation and in the draft constitutions at the Convention up to that point. In the debate that day, while George Mason noted "that the late war could not have been carried on, had such a prohibition existed," the vast majority followed Oliver Ellsworth, who "thought this a favorable moment to shut and bar the door against paper money. The mischiefs of the various experiments which had been made, were now fresh in the public mind and had excited the disgust of all the respectable part of America.” More pointedly, Gouverneur Morris stated, “The monied interest will oppose the plan of Government, if paper emissions be not prohibited.” George Read captured the depth of the Convention's conviction when he noted that if the power to emit paper money was not removed from Congress it "would be as alarming as the mark of the Beast in Revelations." While the history of the Continental dollar provided motivation for this constitutional change, the Convention did not recount that history in any detail. The "mischiefs" that justified prohibiting Congress from issuing anything like the Continental dollar again were presumed to be obvious. ${ }^{5}$

The founding fathers who wanted these changes presented a history of the Continental dollar that justified their actions. The winning side created the "history" as they needed it to be. Subsequent scholars have taken this history at face value, in part because quantity-theory-ofmoney descriptions can be easily grafted onto this history to provide lessons about the folly of fiat money. Those who questioned this history were marginalized—dismissed as depraved inflationists who advocated debt relief through defrauding honest creditors. Thus, few questioned

\footnotetext{
${ }^{5}$ Farrand (1966, v. 2, especially pp. 308-10); Grubb (2006); Smith (1979, v. 4, p. 244).
} 
the traditional story of the Continental dollar or delved deeply into its history. ${ }^{6}$

Federalist anti-paper money rhetoric was generic and superficial. It treated all legislativeissued paper monies as pure fiat currencies prone to excessive emissions, depreciation, and abandonment. Two often-quoted contemporary statements about the Continental dollar illustrate this view. In 1779, Benjamin Franklin, U.S. Ambassador in France wrote, “This Currency as we manage it is a wonderful Machine. It performs its Office when we issue it; it pays \& clothes Troops, \& provides Victuals \& Ammunition; and when we are oblig’d to issue a Quantity excessive, it pays itself off by depreciation.” Franklin described this depreciation as “a Kind of imperceptible Tax, every one having paid a Part of it in the Fall of Value that took Place between his Receiving and Paying such Sums as pass’d thro’ his Hands." ${ }^{7}$ In 1790, Alexander Hamilton, U.S. Treasury Secretary wrote, paper emissions....are of a nature so liable to abuse, ....so certain of being abused, that the wisdom of the Government will be shewn in never trusting itself with the use of so seducing and dangerous an expedient. ... in great and trying emergencies, there is almost a moral certainty of its becoming mischievous. The stamping of paper is an operation so much easier than the laying of taxes, that a government, in the practice of paper emissions, would rarely fail in any such emergency to indulge itself too far...to avoid as much as possible one less auspicious to present popularity. If it should not even be carried so far as to be rendered an absolute bubble, it would at least be likely to be extended to a degree, which would occasion an inflated and artificial state of things incompatible with the regular and prosperous course of political economy. ${ }^{8}$

In other words, Congress recklessly emitted an excessive quantity of fiat currency-

Continental dollars. This led to runaway price inflation (runaway currency depreciation) that destroyed the Continental dollar's value and led to its abandonment. The rhetoric presumes that

\footnotetext{
6 The assessment by Ferguson (1953, pp. 153-5) regarding colonial monetary history applies as well to the Revolutionary and Constitutional eras, and still holds true today.

${ }^{7}$ Oberg (1992, v. 29, p. 356). Franklin's comments are lifted out of context here in a manner typical of the secondary literature and do not convey his full views.

${ }^{8}$ Syrett and Cooke (1963, v. 7, pp. 321-2). Federalist commentary on paper money goes no deeper. The most common word Federalists used to describe paper money was "mischievous," which was a purely rhetorical device as the word itself does not mean anything, but its use frightened people.
} 
congressmen are by nature irrational, myopic, stupid, and ill-motivated to serve the public interest in monetary matters. If they had monetary power, they would mindlessly run off a cliff and crash the system. The history of the Continental dollar proves it.

\section{NOT SO FAST-THERE IS ANOTHER STORY}

A different economic perspective of the Continental dollar is offered here, one that delves through the details of the original documentary evidence to reevaluate (1) the nature of this paper money, (2) what Congress and the public knew about this paper money, (3) how price indices and depreciation tables were constructed and so what they mean regarding the value of Continental dollars at different points in time, and (4) how Congress changed the monetary rules late in the war. These reevaluations produce an alternative history-one that is more consistent with rational behavior and the historical record than that embodied in the traditional story. It sharpens our understanding of what was at stake economically and politically in the ubiquitous retelling of the traditional story and helps us reparse the motives of the founding fathers for transforming governmental monetary powers in the new U.S. Constitution.

Three observations comprise this alternative perspective. First, the Continental dollar was not a pure fiat currency, but a zero-interest bearer bond. It resembled today’s U.S. savings bonds more than today's U.S. dollar bills. As such, the current par value of a Continental dollar was not its face value, but its present value, namely its face value reduced by time-discounting from its fixed future redemption (maturity) date. This monetary system was familiar and well understood at the time- - having been used in the late colonial period.

Second, when time-discounting (rational bond pricing) is separated from depreciation, little depreciation occurred before 1779. Many contemporaries and subsequent scholars conflated time-discounting with depreciation. The plausibility of the traditional story as told by these 
scholars rests on this mistake. Third, Congress changed the redemption rules in 1779 and again in 1780 in ways that were not fiscally feasible, causing Congress' commitment to the Continental dollar to lose credibility. True depreciation, namely that beyond time-discounting, and the collapse of the Continental dollar monetary system followed shortly thereafter.

This alternative perspective involves the subtle and thorny question: "what is fiat money?” Conventional monetary models in the quantity-theoretic tradition too often just assume money or, more precisely, assume that the opportunity cost of using money to execute current transactions is infinite. No transactions can occur without using money. In other words, a fiat money’s liquidity premium over the next best alternative means of executing transactions is large enough to anchor its exchange value given its quantity relative to the quantity of real transactions in the economy. This view of fiat money presumes that only a single money, or single mode of executing transactions, exists. The traditional story and quantity-theory-of-money explanations of the Continental dollar rest on this assumption.

Alternatively, if there are numerous near-perfect substitute monies in use, then the opportunity cost of using one particular money to execute current transactions is no longer infinite, but instead near zero. That money has no excess liquidity premium anchoring its exchange value. Under such conditions, simple quantity-theoretic monetary models are no longer applicable. Instead, the real value of that money rests on its contractual claim to real assets or its exchangeability for other monies that are independently anchored to real values.

The Continental dollar was issued into such a money-rich environment and everyone, including Congress, knew this. During the Revolution, every state issued its own separate and distinct legal-tender paper monies that circulated alongside Continental dollars. In total face value, states as a group issued almost as much of their own paper money as Congress issued 
Continental dollars. Small quantities of imported gold and silver coins were also in circulation and ubiquitous book credit functioned as an efficient near money. ${ }^{9}$ Thus, the Continental dollar possessed no excess liquidity premium. It had a zero opportunity cost for executing current transactions because numerous alternative monies existed that were as good.

As such, the alternative perspective offered here is radical. It turns the assumption embedded in the conventional monetary models that underlay the traditional story of the Continental dollar on its head. Instead of assuming that the opportunity cost of using Continental dollars to execute current transactions is infinite, it assumes it is zero, namely that Continental dollars possessed no excess liquidity premium. Therefore, the value and performance of the Continental dollar depends on its structural design and linkage to real assets or other monies in the economy rather than just on its quantity in circulation. ${ }^{10}$ It is that structural design which will be addressed next, followed by assessing the implications of that design for measuring the value of Continental dollars. The last section addresses how Congress altered that design thereby precipitating the collapse of the system.

\section{INITIAL DESIGN AND IDEAL PERFORMANCE}

In a series of resolutions from 22 June through 26 December 1775, Congress determined the amount, value, and redemption structure of the first two emissions of Continental dollars, see Table 1. Congress maintained this design in all subsequent emissions, changing only the amounts issued and denominational spacing. Congressional debates were private and the delegates were

\footnotetext{
${ }^{9}$ Grubb (2012b, 2012c); Newman (1997); Ratchford (1941, p. 34).

10 The conceptual framework underlying the approach here owes much to the recent work in macroeconomics on the fiscal structure of money and credit. For a brief and reasonably accessible summary, see Sargent (2012, pp. 110). Unfortunately, theorists tend to apply their new macroeconomic modeling insights to history as though the historical record is some neutral bag of facts rather than something that is highly constructed by prior scholars using other paradigms and older models, e.g. see the assessment of Ferguson (1953, pp. 153-5). They try to fit this highly constructed historical record into their new paradigm. This method is backwards. History needs to be reconstructed first - stripped of its older infecting prejudices that filtered and shaped the original evidence. The approach here is to have these newer theoretical insights in mind when using the primary and original sources to reconstruct the historical record anew, making this newer historical record more coherent, consistent, and complete in the process.
} 
Table 1 Continental Dollar Redemption/Maturity Dates Set by Congressional Legislation

\begin{tabular}{|c|c|c|c|c|c|}
\hline $\begin{array}{l}\text { Procedural } \\
\text { Authorization } \\
\text { Dates }\end{array}$ & $\begin{array}{l}\text { Date Printed } \\
\text { on the Bill } \\
\text { (Emission \#) }\end{array}$ & $\begin{array}{l}\text { Stated Spec } \\
\text { Redemptior } \\
\text { Option }\end{array}$ & $\begin{array}{l}\text { cie } \\
\text { n Redemption/Maturity Dates }\end{array}$ & $\begin{array}{l}\text { Current New } \\
\text { Emission }\end{array}$ & $\begin{array}{l}\text { Applied to Other } \\
\text { Emissions }\end{array}$ \\
\hline July 29, 1775 & $\begin{array}{l}\text { May 10, } 1775 \\
(\text { Emission \#1) }\end{array}$ & yes & $\begin{array}{l}1 / 4 \text { on or before Nov. } 30,1779 \\
1 / 4 \text { on or before Nov. } 30,1780 \\
1 / 4 \text { on or before Nov. } 30,1781 \\
1 / 4 \text { on or before Nov. } 30,1782\end{array}$ & $\$ 1,000,000$ & $\begin{array}{l}\$ 2,000,000 \text { from } \\
\text { 22 June } 1775\end{array}$ \\
\hline Dec. 26, 1775 & $\begin{array}{l}\text { Nov. 29, } 1775 \\
\text { (Emission \#2) }\end{array}$ & yes & $\begin{array}{l}1 / 4 \text { on or before Nov. } 30,1783 \\
1 / 4 \text { on or before Nov. } 30,1784 \\
1 / 4 \text { on or before Nov. } 30,1785 \\
1 / 4 \text { on or before Nov. } 30,1786\end{array}$ & $\$ 3,000,000$ & \\
\hline Feb. 21, 1776 & $\begin{array}{l}\text { Feb. 17, } 1776 \\
\text { (Emission \#3) }\end{array}$ & --- & $\begin{array}{l}\text { "on the same security as the sums } \\
\text { of money heretofore emitted..." }\end{array}$ & $\begin{array}{l}\$ 4,000,000 \\
{[\$ 3,937,220 \mathrm{pr}}\end{array}$ & ted only] \\
\hline May 22, 1776 & $\begin{array}{l}\text { May 9, } 1776 \\
\text { (Emission \#4) }\end{array}$ & yes $^{\mathrm{a}}$ & $\begin{array}{l}\text { "in such manner...as Congress } \\
\text { shall hereafter direct...”, }\end{array}$ & $\$ 5,000,000$ & \\
\hline Aug. 13, 1776 & $\begin{array}{l}\text { July 22, } 1776 \\
\text { (Emission \#5) }\end{array}$ & yes $^{a}$ & 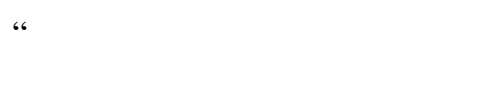 & $\$ 5,000,000$ & \\
\hline Nov. 2, 1776 & $\begin{array}{l}\text { Nov. 2, } 1776 \\
\text { (Emission \#6) }\end{array}$ & --- & “ & $\$ 5,000,000$ & \\
\hline Feb. 26, 1777 & $\begin{array}{l}\text { Feb. 26, } 1777 \\
\text { (Emission \#7) }\end{array}$ & --- & $\begin{array}{l}\text { "periods...that shall be fixed } \\
\text { by Congress...", }\end{array}$ & $\$ 5,000,000$ & \\
\hline May 22, 1777 & $\begin{array}{l}\text { May 20, } 1777 \\
\text { (Emission \#8) }\end{array}$ & --- & nothing & $\$ 5,000,000$ & \\
\hline Aug. 15, 1777 & $“$ & --- & “ & $\$ 1,000,000$ & \\
\hline Nov. 7, 1777 & “ & --- & “ & $\$ 1,000,000$ & \\
\hline Dec. 3, 1777 & “ & --- & “ & $\$ 1,000,000$ & \\
\hline Jan. 8, 1778 & “ & --- & “ & $\$ 1,000,000$ & \\
\hline Jan. 22, 1778 & “ & --- & “ & $\$ 2,000,000$ & \\
\hline Feb. 16, 1778 & “ & --- & “ & $\$ 2,000,000$ & \\
\hline Mar. 5, 1778 & “ & --- & “ & $\$ 2,000,000$ & \\
\hline Apr. 4, 1778 & “ & --- & “ & $\$ 1,000,000$ & \\
\hline Apr. 11, 1778 & $\begin{array}{l}\text { Apr. 11, } 1778 \\
\text { (Emission \#9) }\end{array}$ & --- & “ & $\$ 5,000,000$ & \\
\hline Apr. 18, 1778 & $\begin{array}{l}\text { May 20, } 1777 \\
(\text { Emission \#8) }\end{array}$ & --- & “ & $\$ 500,000$ & \\
\hline May 22, 1778 & $\begin{array}{l}\text { Apr. 11, } 1778 \\
\text { (Emission \#9) }\end{array}$ & --- & “ & $\$ 5,000,000$ & \\
\hline June 20, 1778 & “ & --- & “ & $\$ 5,000,000$ & \\
\hline July 30, 1778 & “ & --- & “ & $\$ 5,000,000$ & \\
\hline Sept. 5, 1778 & “ & --- & “ & $\$ 5,000,000$ & \\
\hline
\end{tabular}




\begin{tabular}{|c|c|c|c|c|c|}
\hline Sept. 26, 1778 & $\begin{array}{l}\text { Sept. 26, } 1778 \\
\text { (Emission \#10) }\end{array}$ & --- & “ & $\$ 10,000,100$ & \\
\hline Nov. 4, 1778 & “ & --- & “ & $\$ 10,000,100$ & \\
\hline Dec. 14,1778 & “ & --- & “ & $\$ 10,000,100$ & \\
\hline Jan. 2, 1779 & $\begin{array}{l}\text { Jan. 14, } 1779 \\
\text { (Emission \#11) }\end{array}$ & yes ${ }^{b}$ & $\begin{array}{l}\$ 15,000,000 \text { for } 1779 \text { and } \\
\text { annually } \$ 6,000,000 \text { for } 18 \\
\text { years to } 1 \text { January } 1797 \text {, with } \\
\text { any additional emissions in } \\
1779 \text { redeemed in the same } \\
\text { manner and within the same } \\
\text { time period }^{\mathrm{C}}\end{array}$ & $\$ 8,500,400$ & $\begin{array}{l}\text { applies to all } \\
\text { prior emissions } \\
\text { and to all } \\
\text { subsequent } \\
\text { emissions to } \\
1780\end{array}$ \\
\hline Feb. 3, 1779 & $\begin{array}{l}\text { Jan. 14, 1779 }{ }^{\mathrm{d}} \\
\text { (Emission \#11) }\end{array}$ & yes ${ }^{b}$ & nothing new added & $\$ 5,000,160$ & \\
\hline Feb. 19, 1779 & “ & yes ${ }^{b}$ & “ & $\$ 5,000,160$ & \\
\hline April 1, 1779 & “ & yes ${ }^{b}$ & “ & $\$ 5,000,160$ & \\
\hline May 5, 1779 & “ & yes ${ }^{b}$ & “ & $\$ 10,000,100$ & \\
\hline June 4, 1779 & “ & yes ${ }^{b}$ & “ & $\$ 10,000,100$ & \\
\hline July 17, 1779 & “ & yes ${ }^{b}$ & “ & $\$ 15,000,280$ & \\
\hline Sept. 17, 1779 & “ & yes ${ }^{b}$ & “ & $\$ 15,000,260$ & \\
\hline Oct. 14,1779 & “ & yes ${ }^{b}$ & “ & $\$ 5,000,180$ & \\
\hline Nov. 17, 1779 & “ & yes ${ }^{b}$ & “ & $\$ 10,050,540$ & \\
\hline Nov. 29, 1779 & “ & yes ${ }^{b}$ & “ & $\$ 10,000,140$ & \\
\hline
\end{tabular}

Source: Grubb (2008, p. 286; 2012a); JCC (v. 2, pp. 103, 105, 207, 221-3; v. 3, pp. 390, 398, 407, 457-9; v. 4, pp. 156-7, 164-5, 339-40, 374, 380-3; v. 5, pp. 599, 651, 724-8; v. 6, pp. 918, 1047; v. 7, p. 161; v. 8, pp. 377-80, 646-7; v. 9, pp. 873-4, 993; v. 10, pp. 26, 28, 36, 82-3, 86, 174-5, 223-5, 308-12, 337-8, 364-5; v. 11, pp. 521-4, 627, 731-2; v. 12, pp. 884, 962, 967, 1073, 1100-01, 1133, 1217-18, 1266; v. 13, pp. 19-21, 64-5, 139-41, 209-10, 408-9, 420-1; v. 14, pp. 548-9, 683-4, 687-8, 847-9; v. 15, pp. 1076-8, 1171-2, 1285, 1324-5); Papers of the Continental Congress [PCC hereafter] (m247, reel 33, item 26, 'Reports of the Committee on the Treasury and Finance, 1776-1788', pp. 1-5, 13-14; m247, reel 145, item 136, 'Reports of the Board of Treasury, 1776-1781, Volumes 1-2 (1776-1778)', v. 1, pp. 181, 355-7, 462, 507; v. 2, pp. 29, 83, 125, 199, 217, 373, 427, 529, 573, 669, 761; m247, reel 146, item 136, 'Reports of the Board of Treasury, 1776-1781, Volume III 1779', pp. 69, 111, 209, 215, 351, 477, 641, 727, 817, 845).

Notes: Dates are for when procedural details were given for each emission. An emission is all bills issued with the same date printed on the bill (Newman 1997, pp. 58-69). The date printed on the bill was the only way the public could distinguish between bills of different emissions and hence between bills with different redemption procedures. Some emissions had several authorizing resolutions in terms of when additional amounts were added to an emission.

${ }^{\mathrm{a}}$ Stated in coinage rating resolutions but not in emission resolutions (JCC v. 4, pp. 339-40, 382; v. 5, p. 724; v. 7, p. 36).

${ }^{\mathrm{b}}$ See fn. 41.

c By the end of 1779 a total of $\$ 199,990,000$ net new Continental dollars had been emitted. To redeem all the Continental dollars as the 2 January 1779 resolution specified would entail raising the annual payments over the 
18 year period from 1780 to 1797 from $\$ 6,000,000$ to $\$ 10,277,778$.

${ }^{\mathrm{d}}$ Some bills belonged to emission \#10.

sworn to secrecy. Why congressmen structured the Continental dollar this way must be deduced from their actions. ${ }^{11}$

The face value of a Continental dollar was set equal to a Spanish silver dollar—so indicated on the face of each bill. For the first emission, the initial three million—-those with the date May 10, 1775 printed on the bills, Congress passed redemption instructions on 29 July 1775. States were to remit fixed quotas of Continental dollars to the Continental treasury to be burned. Each state's quota was roughly proportional to its respective population share in the union. Congress explicitly left each state free to decide how best to redeem Continental dollars from the citizens within its jurisdiction. State remittances to the Continental treasury were to be in four equal yearly installments spread over a contiguous four-year period, beginning on 30 November 1779 and ending on 30 November 1782. No contemporaneous taxes or other debts payable to the states in these Continental dollars were required before the redemption years indicated. No state was required to remit more than its quota, and Continental dollars paid no interest. States with a quota deficiency of Continental dollars were to make it up in specie at face value. The Continental treasurer was to retain this specie and advertise its availability. Citizens with Continental dollars in states that had filled their quotas and had ceased redeeming Continental dollars could redeem them at face value in specie directly from the Continental treasury, in effect claiming the specie remitted by the states with a quota deficiency of Continental dollars. ${ }^{12}$

For the second emission, the next three million—-those with the date November 29, 1775 printed on the bills, Congress passed redemption instructions on 26 December 1775 . These

\footnotetext{
${ }^{11}$ See JCC (v. 2-3); Newman (1997, pp. 58-69). The private letters written by congressmen reveal little (Smith 1976, v. 1-2).

12 JCC (v. 2, pp. 221-3).
} 
instructions were identical to those for the first emission, except that the four-year redemption period was explicitly voted to be moved forward to begin after the last of the first emission was redeemed, namely to begin on 30 November 1783 and end on 30 November $1786 .{ }^{13}$ In short, the Continental dollar was a zero-interest bearer bond. It resembled today's U.S. savings bonds more than today's U.S. dollar bills, with the exception that it was transferable. As such, the current par value of a Continental dollar was not its face value, but its present value, namely its face value reduced by time-discounting from its fixed future redemption (maturity) date.

Roger Sherman, delegate to the Continental Congress from Connecticut and member of one of that body's finance committees, in a letter to the Governor of Connecticut on 27 October 1778 gave a clear explanation of the nature of the Continental dollar. He wrote,

A note for $£ 100$ on compound interest, payable at the expiration of 20 years would be equal to one for $£ 321$ for the same term without interest. If the Bills of public credit [Continental dollars], so far as they exceed a sufficient quantity for a medium of trade, are to be considered only as securities for money without interest, rebating the compound interest for the time before they are redeemable will determine their present value, and they will gradually appreciate as time of their redemption approaches. Enclosed is a computation of the annual increase of $£ 100$ for 21 years on compound interest. ${ }^{14}$

The distinct bearer-bond nature of the Continental dollar could also be gleaned from what was printed on the face of each Continental bill, namely "THIS BILL entitles the Bearer to receive [the amount printed on the face of the bill] Spanish milled DOLLARS, or the Value thereof in Gold or Silver, according to the Resolutions of CONGRESS, held at Philadelphia, [date of authorizing legislation for this emission].” The congressional resolution referred to on the bill laid out the redemption or maturity dates when the bearer would receive the Spanish silver dollars, or value thereof, designated on the face of the bill. This language differed from that typically printed on colonial paper monies which indicated that colonial bills were intended to be

\footnotetext{
13 See JCC (v. 3, pp. 457-9); Smith (1977, v. 2, pp. 517-8, 524).

${ }^{14}$ Smith (1985, v. 11, pp. 136, 306-7).
} 
used more as current money than long-term bonds, namely "This BILL by LAW shall pass current in [colony's name], for [the amount printed on the face of the bill].”15 Language was important and precisely used. Everyone could see and grasp the difference.

Congress' redemption instructions were widely disseminated. Congress circulated a handbill that contained its Continental dollar resolutions passed before 30 July 1775, including all the relevant redemption provisions. ${ }^{16}$ This handbill was reprinted in numerous newspapersthe first being in the Connecticut Journal, \& New-Haven Post-Boy, 25 October 1775. Between 25 October and 4 December 1775 all three newspapers in Connecticut, three of the four in Massachusetts, one of the two in Rhode Island, one of the four in New York, and two of the five in Pennsylvania reprinted it. Out of the surviving newspapers consulted, 10 of the 24 reprinted the handbill. ${ }^{17}$ The redemption procedures covering the second emission were reprinted in The Pennsylvania Evening Post, 12 March 1776. This information was also disseminated when Congress published its journals at the end of 1775 and later in $1776 .{ }^{18}$ The public was well informed of the structural design of the Continental dollar.

For the next eight emissions (emissions \#3 through \#10), totaling \$95,500,300 in face value, no explicit redemption instructions were issued, see Table $1 .{ }^{19}$ At best, instructions indicated that redemption would be “on the same security as the sums of money heretofore

15 See Grubb (2012b); Newman (1997) [italic and capitalization in the original].

${ }^{16}$ United States, Continental Congress (Philadelphia?: s.n. 1775) http://memory.loc.gov/service/rbc/bdsdcc/00301/0001.jpg [accessed 30 January 2013].

17 Grubb (2012a, pp. 151-2).

18 See JCC (v. 2, p. 208; v. 3, pp. 263-4, 393, 427); Smith (1976, v. 1, pp. 503, 525-6, 695; 1980, v. 6, p. 404; 1986, v. 13, p. 383; 1988, v. 15, p. 484). The Constitutional Gazette, 20 December 1775; New-York Gazette and the Weekly Mercury, 25 December 1775; New-York Journal; or, The General Advertiser, 21 December 1775; The Pennsylvania Journal; and the Weekly Advertiser, 13 December 1775; and the Pennsylvania Gazette, 23 October 1776 advertised the proceedings of the Continental Congress for sale.

19 After 1775, Congress shifted monetary issues from Congress, sitting as a whole, to congressional subcommittees, JCC (v. 4, pp. 156-7); Smith (1978, v. 3, pp. 270-1). Redemption instructions for subsequent emissions fell between these administrative cracks. Not until emission \#11 did Congress, sitting as a whole, resolve this administrative lapse, see Table 1. 
emitted by Congress have been," "in such manner...as Congress shall hereafter direct," and for “periods...that shall be fixed by Congress.” But most often, nothing was said. The pattern of redemption for these emissions, however, could be deduced from the pattern set by Congress for the first two emissions. Redemption had been set far into the future, when the war would likely be over, with redemption intervals consistent with feasible and historically acceptable tax levels. Across the first two emissions, the redemption of just \$750,000 each year implied a tax per white-capita per year for redeeming just Continental dollars of $\$ 0.33$. In the 13 colonies between 1770 and 1774 , the average tax per white-capita per year for all taxes was $\$ 0.41 .{ }^{20}$ The forwardshifting contiguous four-year redemption pattern across the first two emissions is difficult to explain except in reference to maintaining a fiscally credible per white-capita per year tax level for retiring Continental dollars at face value.

This monetary system was familiar and well understood at the time—-having been used in the late colonial period. New Jersey's financing of the French and Indian War, 1755-1764, is illustrative. ${ }^{21}$ Each year the war continued, New Jersey issued more bills of credit to meet unexpected war expenses until by 1764 a total of 347,500 New Jersey pounds, approximately

\footnotetext{
${ }^{20}$ Derived from Bezanson (1951, p. 344); Boyd (1954, v. 10, pp. 42-3); Carter, et al. (2006, v. 1, p. 25; v. 5, pp. 652-3); Grubb (2008); McCusker (1978, p. 10); Rabushka (2008, pp. 796, 825, 862-3). Congress placed the redemption of the first emission four to seven years into the future because that was when the war was expected to be over, e.g. Silas Deane, congressman from Connecticut, wrote 1 July 1775, "The Warr will not last Seven Years if I have any Judgment in Matters" (Smith 1976, v. 1, p. 567). At that point, trade would resume and generate the income necessary to pay the taxes needed to redeem Continental dollars at face value.

${ }^{21}$ Derived from Bush (1980, pp. 15-39, 65-74, 81-2, 104, 124-7, 168-72, 195-213, 219-51, 269-88, 303-4, 307-19, 323-4, 327-55, 373-409, 413-36, 451-88, 495-502, 517-31, 539-55, 559-78, 581-97, 621-56, 663-79; 1982, pp. 5-13, 24-8, 73-89, 97-103, 107-11, 125-40, 153-4, 159-66, 191-8, 207-21, 273-6, 289-316, 385-8, 394, 427-31, 453-6, 505-8, 523-64; 1986, pp. 25-9, 53-9, 64-8, 115-21, 171-7, 212-35, 250-1, 301-6, 327-32, 379-93, 419-22, 437-56); Fisher (1911, p. 289); Grubb (2012b); Kemmerer (1940, p. 279; 1956, p. 136); Lester (1939, pp. 197, 199); Newman (1997, pp. 243-54); Sherwood (1851, p. 147); Wicker (1985, p. 874). Per capita amounts rely on population estimates presented in Carter, et al. (2006, v. 5, p. 652) with interpolated values between the reported decadal estimates. Currency conversions are taken from McCusker (1978, pp. 8-10). In face value, $1 £_{\mathrm{NJ}}$ (New Jersey pound) $=2.9163$ ounces of silver $=0.2583 £_{\mathrm{S}}$ (pounds sterling). This means that $1.3275 £_{\mathrm{NJ}}=1 £_{\mathrm{S}}=\$ 4.5457$ (Spanish silver dollars), or $1 £_{\mathrm{NJ}}=\$ 3.4243$. Richard Smith, delegate from New Jersey to the Continental Congress from 1774 into 1776, was appointed by Congress to its new standing committee created on 17 February 1776 for superintending the treasury which was in charge of emissions of bills of credit, JCC (v. 4, pp. 156-7).
} 
$\$ 1,189,944$, in new bills had been emitted. This was over 2.5 times the amount New Jersey had emitted over its entire prior history of issuing paper money (1709-1754).

Like the future Continental dollar, these New Jersey bills had a zero-interest bearer-bond structure with their redemption value in specie printed directly on their face. With each new emission, the New Jersey legislature established explicit redemption provisions (maturity dates) by fixing future tax obligations to be paid in those bills. Bills redeemed via taxation were destroyed. As the war continued and emissions mounted, the legislature deliberately spread these redemptions evenly over a 27 year time horizon, from 1757 through 1783 . Between the last wartime emission in 1764 and 1773, redemption was set at 12,500 and from 1774 to 1782 at 15,000 New Jersey pounds per year. This put the average redemption tax per white-capita per year for New Jersey residents between $\$ 0.37$ and $\$ 0.45$. The deliberate effort by the New Jersey legislature to spread redemption evenly over a long horizon held per white-capita per year taxes within feasible limits, thus giving New Jersey’s commitment to its paper money credibility. New Jersey successfully redeemed its bills at face value on time as legislatively promised until the Revolution intervened.

Such recent experiences influenced the formation of expectations with regard to how the Continental dollar would operate. Sizable emissions of bills during a war would not be redeemed until after that war had ended, and redemption would be spread over a long enough time horizon to keep per year per white-capita redemption taxes within feasible limits thus giving the system fiscal credibility. Using the pattern set by Congress for the first two emissions of Continental dollars, those issued in 1775, and expectations based on how the colonies had financed the French and Indian War, the public could forecast the unspecified redemption structure for the next eight emissions of Continental dollars, those issued in 1776 through 1778. In particular, 
redemption would be pushed successively into the future with each subsequent emission and spread over enough years to keep tax levels within feasible limits.

Three forecasts are consistent with the redemption pattern set by Congress in 1775. First, a four-year contiguous redemption interval would be maintained for each subsequent emission starting the year after the redemption interval for the immediately prior emission ended (Forecast 1). Second, redemption intervals would be adjusted to maintain a constant and feasible per year per white-capita tax level until all emissions were redeemed at face value, with $\$ 0.33$ being used here to represent that level (Forecast 2). Third, redemption intervals would be adjusted to maintain a constant $\$ 750,000$ per year redemption rate until all emissions were redeemed at face value (Forecast 3). Forecasts 1 and 2 are used to represent the public's expectation about future redemptions of Continental dollars. Forecast 1 is identical to Forecast 3 when emission sizes are identical, which is approximately true for emissions \#1 through \#7. After emission \#7, emission sizes get so large that by 1779 Forecast 3 would entail a redemption period of 267 years. As such, Forecast 3 is redundant before and unrealistic after 1777, and so is not used.

Table 2 presents the expected average par present value of a Continental dollar based on face-value redemption dates, both legislated and forecasted, using a 6 percent discount (interest) rate. $^{22}$ Forecast 1 is used to calculate the expected average par present value at inception of emissions \#3 through \#10. Table 2 also presents the expected average par present value of the accumulated total Continental dollars emitted to that date weighted by the dollar size of emissions, using both Forecast 1 and Forecast 2 for emissions \#3 through \#10 and legislated

\footnotetext{
22 Six percent was the rate used by the national government for loans between 1776 and 1790, see Homer and Sylla (1991, pp. 274-313); JCC (v. 6, p. 1037; v. 7, pp. 102-3, 158; v. 8, pp. 725-6; v. 9, pp. 955, 989; v. 12, p. 929; v. 14, pp. 717, 783; v. 16, pp. 264-5; v. 17, pp. 464, 568); Pennsylvania Gazette (30 April; 21 and 28 May; 25 June; 2, 16, and 23 July 1777); Puls (2008, p. 181); Smith (1979, v. 4, p. 295; 1980, v. 6, pp. 212-3, 228-9, 260-2, 277, 295, 346, 400-4; 1981, v. 7, p. 617; 1983, v. 10, p. 205; 1985, v. 11, pp. 94, 138, 361; 1986, v. 13, p. 604; 1987, v. 14, pp. 463, 500; 1989, v. 16, pp. 307-8, 490, 531; 1990, v. 17, p. 365). On 6 percent being a typical or normal interest rate in eighteenth-century America, see Brock (1975, pp. 260, 328, 332, 435, 462); Davis (1964, v. 1, p. 326; v. 2, pp. 38, 68, 83, 99-100, 315, 321; v. 3, p. 168; v. 4); Nettels (1934, p. 267).
} 
Table 2 Legislated/Forecasted Redemption Dates and Valuations for Continental Dollar Emissions

\begin{tabular}{|c|c|c|c|c|c|c|c|}
\hline $\begin{array}{l}\text { Emission \# } \\
\text { Date Printed } \\
\text { on the Bills: } \\
\text { (Amount } \\
\text { Referenced) }\end{array}$ & $\begin{array}{l}\text { Maturity/ } \\
\text { Redemption } \\
\text { Interval } \\
(\mathrm{L})=\text { Legislated } \\
(\mathrm{F})=\text { Forecast } 1\end{array}$ & $\begin{array}{l}\text { Expected } \\
\text { Present Value } \\
\text { at Inception }^{\mathrm{a}} \\
\text { [Cumulative] } \\
\text { \{Forecast } 2\} \\
100=\text { par }\end{array}$ & $\begin{array}{l}\text { Thomas } \\
\text { Jefferson's } \\
\text { (Bullock's) } \\
\text { Depreciation } \\
\text { Tables } \\
100 \text { = par }\end{array}$ & $\begin{array}{c}\text { JCC } \\
\text { June } \\
28, \\
1780 \\
100=\text { par }\end{array}$ & $\begin{array}{l}\text { Philadelphia } \\
\text { Price Index: } \\
\text { Derived } \\
\text { Valuation }^{c}\end{array}$ & $\begin{array}{l}\text { Philadelphia } \\
\text { Merchant } \\
\text { Account } \\
\text { Book } \\
\text { Valuations } \\
100=\text { par }\end{array}$ & $\begin{array}{l}\text { Implied } \\
\text { Average } \\
\text { Tax Per } \\
\text { Year Per } \\
\text { White- } \\
\text { Capita }\end{array}$ \\
\hline \multicolumn{8}{|l|}{$\# 1$} \\
\hline $\begin{array}{l}\text { May 10, } 1775 \\
(\$ 3,000,000) \\
\# 2\end{array}$ & $\begin{array}{l}\text { Nov. } 301779- \\
\text { Nov. } 30,1782(\mathrm{~L})\end{array}$ & $\begin{array}{l}69.73 \\
{[69.73]}\end{array}$ & $\begin{array}{l}100.0 \\
(100.0)\end{array}$ & & ----- & ----- & $\begin{array}{c}\$ 0.33 \\
{[0.35-0.31]}\end{array}$ \\
\hline $\begin{array}{l}\text { Nov. 29, } 1775 \\
\quad(\$ 3,000,000) \\
\# 3\end{array}$ & $\begin{array}{l}\text { Nov. 30, 1783- } \\
\text { Nov. 30, } 1786 \text { (L) }\end{array}$ & $\begin{array}{l}56.68 \\
{[64.37]}\end{array}$ & $\begin{array}{l}100.0 \\
(100.0)\end{array}$ & & ----- & ----- & $\begin{array}{c}0.28 \\
{[0.30-0.27]}\end{array}$ \\
\hline $\begin{array}{l}\text { Feb. 17, } 1776 \\
\quad(\$ 3,937,220)\end{array}$ & $\begin{array}{l}\text { Nov. 30, 1787- } \\
\text { Nov. 30, } 1790(\mathrm{~F})\end{array}$ & $\begin{array}{c}45.18 \\
{[57.21]} \\
{[\{57.16\}]}\end{array}$ & $\begin{array}{l}100.0 \\
(100.0)\end{array}$ & & 89.6 & ----- & $\begin{array}{c}0.33 \\
{[0.35-0.32]}\end{array}$ \\
\hline \multicolumn{8}{|l|}{ \#4 } \\
\hline $\begin{array}{l}\text { May 9, } 1776 \\
\quad(\$ 5,000,000)\end{array}$ & $\begin{array}{l}\text { Nov. 30, 1791- } \\
\text { Nov. 30, } 1794 \text { (F) }\end{array}$ & $\begin{array}{c}36.03 \\
{[50.48]} \\
{[\{50.38\}]}\end{array}$ & $\begin{array}{l}100.0 \\
(80.0)\end{array}$ & & 66.4 & ----- & $\begin{array}{c}0.36 \\
{[0.38-0.34]}\end{array}$ \\
\hline \#5 & & & & & & & \\
\hline $\begin{array}{l}\text { July } 22,1776 \\
\quad(\$ 5,000,000)\end{array}$ & $\begin{array}{l}\text { Nov. 30, 1795- } \\
\text { Nov. 30, } 1798 \text { (F) }\end{array}$ & $\begin{array}{c}28.70 \\
{[45.65]} \\
{[\{45.35\}]}\end{array}$ & $\begin{array}{l}100.0 \\
(80.0)\end{array}$ & & 65.0 & ----- & $\begin{array}{c}0.32 \\
{[0.33-0.31]}\end{array}$ \\
\hline \multicolumn{8}{|l|}{ \#6 } \\
\hline $\begin{array}{l}\text { Nov. } 2,1776 \\
\quad(\$ 5,000,000)\end{array}$ & $\begin{array}{l}\text { Nov. 30, 1799- } \\
\text { Nov. 30, } 1802 \text { (F) }\end{array}$ & $\begin{array}{c}22.94 \\
{[41.70]} \\
{[\{41.46\}]}\end{array}$ & $\begin{array}{r}100.0^{\mathrm{e}} \\
(66.7)\end{array}$ & & 42.7 & ----- & $\begin{array}{c}0.28 \\
{[0.30-0.27]}\end{array}$ \\
\hline
\end{tabular}

Legal Tender Laws Enacted in 1777 Made All Emissions Fungible and so All Expected Present Values Cumulative \#7

\begin{tabular}{|c|c|c|c|c|c|c|c|}
\hline $\begin{array}{l}\text { Feb. } 26,1777 \\
\quad(\$ 5,000,000) \\
\# 8\end{array}$ & $\begin{array}{l}\text { Nov. 30, 1803- } \\
\text { Nov. 30, } 1806 \text { (F) }\end{array}$ & $\begin{array}{c}38.52 \\
\{38.43\}\end{array}$ & $\begin{array}{l}37.5^{\mathrm{e}} \\
(32.3)\end{array}$ & & 29.9 & 50.0 & $\begin{array}{c}0.31 \\
{[0.38-0.24]}\end{array}$ \\
\hline $\begin{array}{l}\text { May 20, } 1777 \\
(\$ 16,500,000) \\
\# 9\end{array}$ & $\begin{array}{l}\text { Nov. 30, 1807- } \\
\text { Nov. 30, } 1810 \text { (F) }\end{array}$ & $\begin{array}{c}30.40 \\
\{30.02\}\end{array}$ & $\begin{array}{l}37.5^{\mathrm{e}} \\
(33.3)\end{array}$ & & 20.9 & 40.0 & $\begin{array}{c}0.36 \\
{[0.76-0.24]}\end{array}$ \\
\hline $\begin{array}{l}\text { Apr. } 11,1778 \\
(\$ 25,000,000) \\
\# 10\end{array}$ & $\begin{array}{l}\text { Nov. 30, 1811- } \\
\text { Nov. 30, } 1814 \text { (F) }\end{array}$ & $\begin{array}{c}25.11 \\
\{23.52\}\end{array}$ & $\begin{array}{l}16.7^{\mathrm{e}} \\
(20.0)\end{array}$ & $57.1^{j}$ & 11.7 & 20.0 & $\begin{array}{c}0.43 \\
{[1.03-0.24]}\end{array}$ \\
\hline $\begin{array}{l}\text { Sept. 26, } 1778 \\
(\$ 30,000,300) \\
\# 11\end{array}$ & $\begin{array}{l}\text { Nov. 30, 1815- } \\
\text { Nov. 30, } 1818 \text { (F) }\end{array}$ & $\begin{array}{c}21.09 \\
\{18.54\}\end{array}$ & $\begin{array}{l}20.0^{\mathrm{e}} \\
(16.7)\end{array}$ & 25.0 & 11.5 & 20.0 & $\begin{array}{c}0.49 \\
{[1.09-0.24]}\end{array}$ \\
\hline $\begin{array}{r}\text { Jan. } 14,1779^{\mathrm{g}} \\
(\$ 199,990,000) \\
\text { Counter } \\
\text { Counter }\end{array}$ & $\begin{array}{l}\text { Nov. 30, 1779- } \\
\text { Jan. 1, } 1797 \quad \text { (L) } \\
\text { factual Forecast 1: } \\
\text { factual Forecast 2: }\end{array}$ & $\begin{array}{c}62.38 \\
14.78 \\
\{10.59\}\end{array}$ & $\begin{array}{r}12.5^{\mathrm{e}} \\
(5.9)\end{array}$ & 10.0 & 5.6 & 10.0 & $\begin{array}{c}3.66^{\mathrm{g}} \\
{[6.95-2.59]}\end{array}$ \\
\hline $\begin{array}{l}\text { All Emissions }{ }^{\mathrm{h}} \\
(\$ 199,990,000)\end{array}$ & $\begin{array}{l}\text { April 1780- } \\
\text { April } 1781 \quad \text { (L) }\end{array}$ & $2.5^{\mathrm{h}}$ & $\begin{array}{l}2.5^{\mathrm{h}} \\
(2.0)\end{array}$ & 2.5 & 0.7 & 1.7 & $\begin{array}{r}86.72 \\
2.17^{\mathrm{i}}\end{array}$ \\
\hline
\end{tabular}


Sources: Table 1; Bezanson (1951, p. 344); Boyd (1954, v. 10, pp. 42-3); Bullock (1895, p. 135); Carter, et al. (2006, v. 1, p. 36; v. 5, p. 652); Grubb (2008, 2012a); JCC (v. 2, pp. 221-3; v. 3, pp. 457-9; v. 13, pp. 20-1; v. 16, pp. 262-7; v. 17, pp. 567-8); Rabushka (2008, pp. 796, 825, 862-3); Webster (1969, pp. 501-2).

Notes: See Table 1 and the text. Forecasted amounts are based on the pattern set by the first two emissions. Forecast 1 sets a contiguous four-year redemption interval for each emission that starts when the redemption interval for the immediately preceding emission ends. \{Forecast 2 \} sets redemption at a constant $\$ 0.33$ per white-capita per year after 1786. Regarding interest rates, see fn. 22.

${ }^{\text {a }}$ Continuously discounted at 6 percent off the face value on the bill from the redemption interval dates to the date printed on the bill expressed as the value of \$100 in Continental paper money. The numbers in brackets are the expected average par present values for the cumulative emissions outstanding to that date weighted by their dollar size using Forecast 1 . After emission \#6 legal tender laws made all expected values per specific emission cumulative values for all currently outstanding emissions. The numbers in \{\} represent the expected average par present values for the cumulative emissions outstanding to that date weighted by their dollar size using \{Forecast 2$\}$.

${ }^{\mathrm{b}}$ This is the standard depreciation reported throughout the literature, see JCC (v. 17, pp. 567-8); Pennsylvania Gazette (19 July 1780); United States Congress (1834, v. 2, pp. 2243-51). Jefferson reported it as the number of Continental dollars (face value) needed to equal one Spanish silver dollar (Boyd 1954, v. 10, pp. 42-3). That number is converted to a percentage discount off the face value expressed as the value of $\$ 100$ in Continental paper money. The numbers in parentheses are derived from the depreciation rates reported in Bullock (1895, p. 135).

c Constructed from the unweighted Philadelphia price index in Bezanson (1951, p. 344). Base prices were reset to June 1770 through May 1775. This base price was divided by the average of the price index beginning with the month just after the date on the bill listed. Taking the reciprocal of that number and multiplying by 100 equals the number reported in the table. This process yields a comparable number in terms of expected valuation relative to par $=100$, but in this case par equals the average base price from June 1770 through May 1775.

$\mathrm{d}$ The range across the redemption interval is in brackets. Population is extrapolated linearly between decadal benchmarks and is for the white population only (Carter, et al. 2006, v. 1, p. 36; v. 5, p. 652). Only the tax needed to redeem Continental dollars at face value is reported. Taxes are expressed in Spanish silver dollars. Taxes expressed in pounds sterling are converted to Spanish silver dollars following McCusker (1978, p. 10). Legal tender laws merge emission redemptions after emission \#6. Thus, for emissions after emission \#6, the average tax covers redemption across all prior emissions and redemption years. The high number in the tax range for each emission after emission \#6 represents the per year per white-capita tax for the fourth to last year of redemption.

e Jefferson does not list all emissions nor emissions by date. Thus, some dating approximations were necessary.

f Some emissions after 14 January 1779 also had this date on their bills.

g Applies to all past and future net new emissions $(\$ 199,990,000)$ regardless of the date on the bill.

h Enacted 18 March 1780 and covered all past emissions. How to calculate the expected present value at inception is unclear. The resolution's 40 to 1 conversion rate, paper Continental dollars to Spanish silver dollars, is used. See JCC (v. 16, pp. 262-7).

${ }^{\mathrm{i}}$ Evaluated at 40 Continental dollars equals $\$ 1$ in specie as established in the 18 March 1780 resolution.

j JCC (v. 17, p. 568). The dates given in the source for these rates were 1 June 1778, 1 September 1778,1 March 1779, and 18 March 1780, respectively.

redemption dates for emissions \#1, \#2, and \#11. Finally, for emission \#11, Table 2 also reports counterfactual present value estimates using Forecasts 1 and 2 as if the new redemption dates legislated in 1779 were not operative.

Figure 1 uses the calculations in Table 2 to illustrate the ideal expected average par 


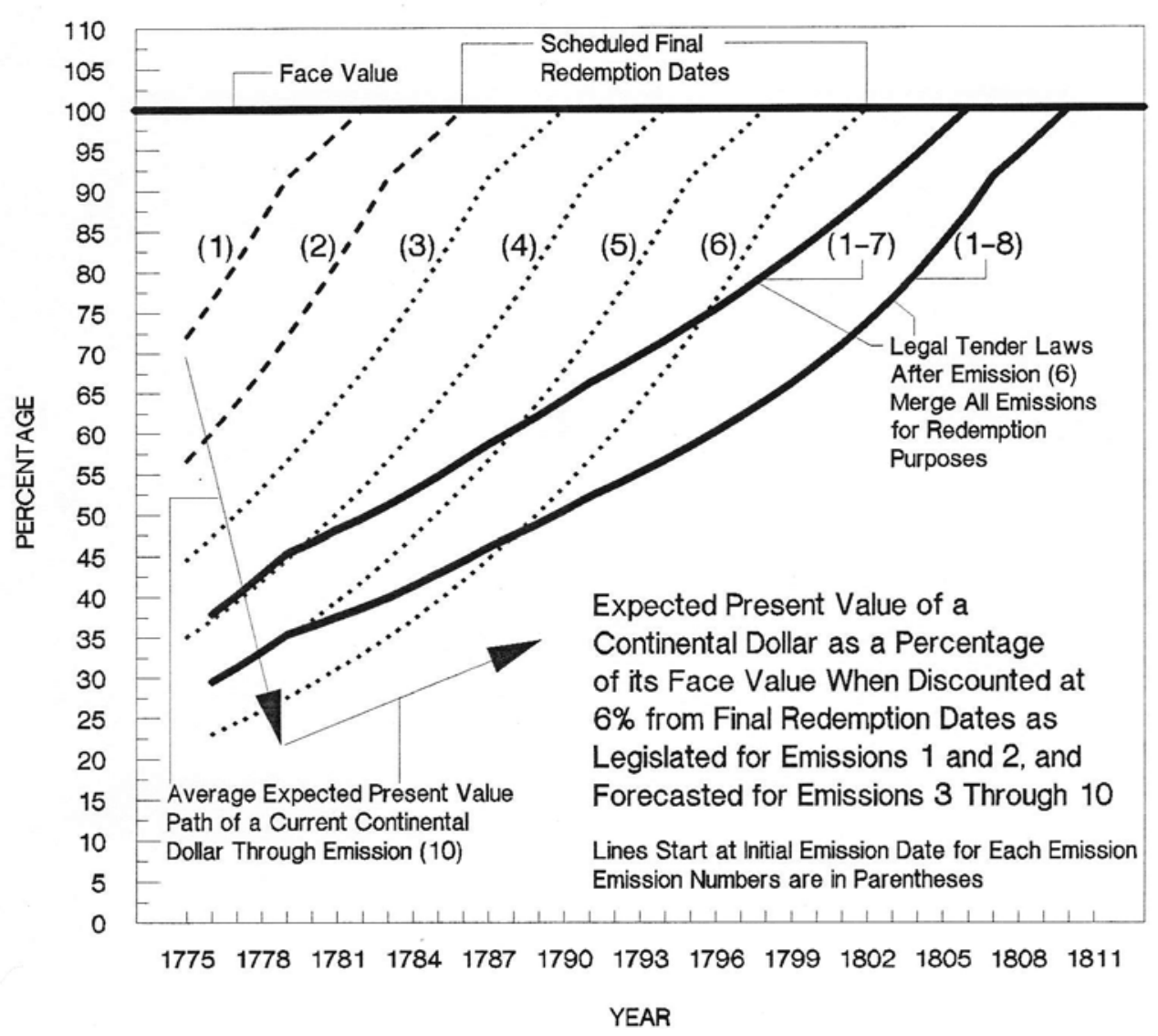

Figure 1 Expected Present Value of a Current Continental Dollar: Face Value Discounted From Final Redemption at 6 Percent for Various Emissions and Cumulative Totals Using Forecast 1

Sources: Derived from the sources and material in Tables 1 and 2.

Notes: See Table 2 and the text for discussion. Emission numbers are in parentheses.

present value of a Continental dollar over time for each emission from inception to maturity

using the legislated redemption dates for emissions \#1 and \#2, and Forecast 1 for the redemption dates for emissions \#3 through \#8 and \#10. Each emission starts at a present value well below its face value due to time-discounting and then rises to its face value by its last redemption date.

While a given emission's average present value is rising over time, the addition of new emissions that start at successively lower discounts pulls down the average present value of all Continental dollars currently outstanding over the years of active emissions.

Congress' initial structural design implies that Continental dollars from different 
emissions should trade contemporaneously at different present values, see Figure 1. Such differences across emissions make for a cumbersome medium of exchange. Before the Revolution, individual colonies solved this problem by making their respective bills of credit (paper monies) a legal tender at face value within their respective jurisdictions. Legal tender laws made bills from different emissions that were currently outstanding fungible, in effect merging emission-specific redemption windows for currently outstanding bills into one big window. As such, legal tender laws allowed the public to respond to what the average expected present value was at each point in time independent of emission dates for all bills currently outstanding. ${ }^{23}$

As expectations of a brief conflict waned and the need for more emissions became apparent, Congress moved to solve the problem of different emissions trading at different present values contemporaneously by asking the states to make Continental dollars legal tender within their respective jurisdictions. On the same day that emission \#4 was authorized, 22 May 1776, a congressional committee consisting of James Duane, George Wythe, John Adams, Roger Sherman, Joseph Hewes, Thomas Johnson, and William Whipple recommended that Congress ask the states to make the Continental dollar a legal tender. The committee, now including Thomas Jefferson, made the same recommendation on 2 September 1776. Finally, on 14 January 1777, after emission \#6 had been authorized, Congress acted on the committee’s recommendation and asked the states to make the Continental dollar a legal tender at face value within their respective jurisdictions. The states moved quickly to accommodate this request. Pennsylvania made the Continental dollar a legal tender after 6 February 1777, Delaware after 22 February 1777, and Virginia after 5 May 1777. By emission \#8, authorized on 22 May 1777,

\footnotetext{
${ }^{23}$ The implementation of legal tender laws had costs, such as increasing the variance in the present value of bills at a point in time when applied to multiple emissions that were currently outstanding. This occurred because merging redemption intervals across emissions currently outstanding created a much longer redemption interval for each current bill. In other words, under a legal tender law, which bills would get redeemed today at face value and which bills would get redeemed in 15 years at face value was indeterminate.
} 
Continental dollars were legal tender at face value. ${ }^{24}$ Figure 1 illustrates the ideal expected average par present value time-path produced by legal tender laws that made the redemption of the first seven, the first eight, and the first ten emissions fungible across the redemption window generated by Forecast 1 for the entire set of emissions included therein, respectively.

A side-effect of imposing legal tender laws was that they pushed the pricing of current transactions into being denominated only in the designated legal tender. Sellers had to price only in the legal tender to avoid being forced to accept bills at above their present value, namely at the legal tender’s face value equivalence to specie monies. By pricing only in the legal tender, sellers could adjust their prices upwards to compensate for the fact that the bill's present value was below its face value. On 13 January 1764, in his longest surviving speech, Benjamin Franklin explained this effect to the Pennsylvania Assembly. In 1788, he reiterated it. In 1776, Adam Smith in the Wealth of Nations explained the same. ${ }^{25}$ The principle was known and understood.

Figure 2 shows this effect in the Philadelphia market. Out of all the commercial transactions in the leading newspaper, the Pennsylvania Gazette, that contained a monetary statement, pricing in dollars did not gain a clear majority of transactions until after January 1777, i.e. until after the Continental dollar had been made a legal tender. Shortly thereafter pricing in dollars rose to capture 80 to 90 percent of all transactions listed. This proportion held into early 1781 when, at Congress' recommendation, states removed the Continental dollar's legal tender

\footnotetext{
${ }^{24}$ See Cushing (1981, v. 2, part 1, pp. 599-602); Hening (1969, v. 9, pp. 297-8); JCC (v. 4, pp. 294, 381-3; v. 5, pp. 608, 724-8; v. 7, pp. 35-7); Smith (1980, v. 6, p. 261); Statutes at large of Pennsylvania (1903, v. 9, pp. 34-40). When a state made the Continental dollar a legal tender within its jurisdiction, this meant that state-imposed fees and taxes could now be paid in Continental dollars at a legally set equivalence to that state's paper money. This may have been an effort to add some current positive liquidity premium to the Continental dollar. Given that states did not remit Continental dollars to the Continental treasury until November 1779, state taxes paid in Continental dollars under the auspices of their being a legal tender did not materially affect the redemption of Continental dollars ahead of that legislatively scheduled and prudently forecast (Grubb 2012a, pp. 156-60, 170).

25 See Grubb (2012b); Labaree (1967, v. 11, pp. 7-18); Smith (1937, p. 311); Smyth (1907, v. 9, p. 638). See also Smith (1985, v. 11, pp. 136, 306-7).
} 


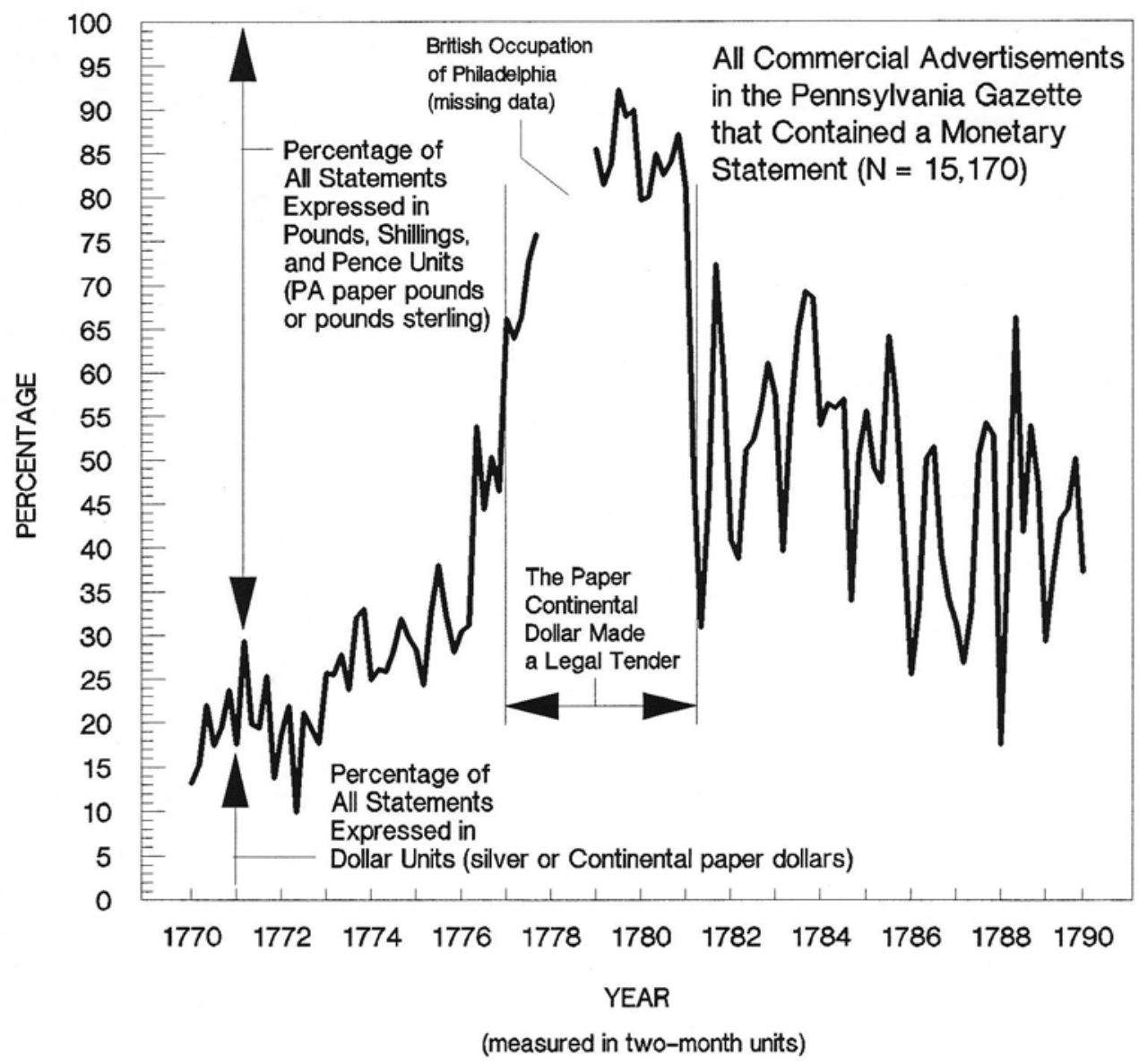

Figure 2 Prevalent Unit of Account in Marketplace Transactions in Philadelphia, 1770 to 1790

Source: Pennsylvania Gazette.

Notes: All commercial advertisements placed in the Pennsylvania Gazette were examined. Data are organized in two-month units. Line breaks indicate missing data (newspapers). Dollar units include Spanish silver dollars and Continental paper dollars. Pounds, shillings, and pence units include Pennsylvania paper pounds and pounds sterling monies.

status in their respective jurisdictions. ${ }^{26}$

With emission \#7, after May 1777, legal tender laws made Continental dollars of

different emissions have the same expected average present value in contemporaneous trades.

\footnotetext{
${ }^{26}$ See Acts of the council and general assembly of New-Jersey (1784, p. 157); Grubb (2012b); Hening (1969, v. 13, pp. 412-3); JCC (v. 16, p. 269); Laws of the state of Delaware (1797, v. 2, pp. 718-9); Smith (1988, v. 15, p. 295; 1990, v. 17, p. 87); Statutes at large of Pennsylvania (1904, v. 10, pp. 204-5, 228-9, 247-9, 337-44). Newspaper price currents, merchant account books, and George Washington's account book all stopped quoting prices in Continental dollars in May of 1781 (Bezanson 1951, pp. 12, 344; Breck 1843, p. 16; Ferguson 1961, p. 66; Webster 1969, p. 502).
} 
Before January 1777, however, Continental dollars from emissions \#1 through \#6 should have traded contemporaneously at different values. Little evidence of differential treatment across emissions pre-1777 has been previously noted, in part because no one has looked for it, which in turn may be due to data difficulties. Market participants typically recorded monetary transactions in units of account and not media of exchange. ${ }^{27}$ For example, in Figure 2, out of 3,127 commercial advertisements placed in the Pennsylvania Gazette between March 1775 and April 1780 that listed a monetary statement, only 3 percent referred to a particular money or media of exchange as opposed to just listing the unit of account used, obscuring value distinctions between particular monies.

Lack of evidence on a value distinction across emissions pre-1777 may also be due to Continental dollars not being extensively used as a medium of exchange pre-1777. Table 3 shows that Continental dollars were large-valued bills. The smallest emitted in 1775 was a \$1 bill, equivalent in face value and expected present value to \$15 and \$11 in 1990 dollars, respectively. Over 60 percent of the bills emitted in 1775, in face value and expected present value, were equivalent to, or larger than, \$50 and \$36 in 1990 dollars, respectively. Large currency denominations were difficult to use as a medium of exchange. Transactions that required change could not be made unless change was given in some other medium. Fractional Continental dollars were only issued in emission \#3, early in 1776, and never again thereafter. When Congress asked the states on 22 November 1777 to stop emitting their own paper monies, they specifically exempted small denomination state paper monies, recognizing that such was needed to make change. ${ }^{28}$ As the expected average present value of a Continental dollar fell with subsequent emissions, the problem of making change in Continental dollars was mitigated, and

27 Bezanson (1951, pp. 3-4, 10-11).

28 JCC (v. 7, p. 125; v. 9, pp. 955-6); Newman (1997, pp. 58-69, 106-10, 121-3, 170-4, 202-11, 235-40, 255-9, 2817, 347-56, 390-6, 415-22, 440-51). See also Smith (1979, v. 4, p. 88). 
Table 3 Paper Currency Pyramids: Volume and Value of Units Issued by Denomination

\begin{tabular}{|c|c|c|c|c|c|c|c|c|}
\hline \multirow{5}{*}{$\begin{array}{l}\text { Continental } \\
\text { Paper Dollar } \\
\text { Denominations }\end{array}$} & \multicolumn{2}{|c|}{$\begin{array}{l}\text { Continental Dollar: } \\
\text { First } 2 \text { Emissions } \\
\text { (All in 1775) }\end{array}$} & \multicolumn{3}{|c|}{$\begin{array}{l}\text { Continental Dollar: } \\
\text { Next } 3 \text { Emissions } \\
\text { (All in 1776) }\end{array}$} & \multicolumn{3}{|c|}{$\begin{array}{l}\text { Comparison with } \\
\text { U.S. Dollar Paper } \\
\text { Currency in } 1990\end{array}$} \\
\hline & \multicolumn{2}{|c|}{ \$6 million in: } & \multicolumn{2}{|c|}{ \$19 million in: } & \multicolumn{4}{|l|}{ Approximate } \\
\hline & Units & Value & Units & Value & Equivalence of & & Units & Value \\
\hline & Issued & Issued & Issued & Issued & 1775-1776 Bills & & Issued & Issued \\
\hline & $\%$ & $\%$ & $\%$ & $\%$ & in 1990 Values $^{\mathrm{a}}$ & & $\%$ & $\%$ \\
\hline & & & & & & $\$ 1$ bill & 37.8 & 1.9 \\
\hline$\$ 1 / 6$ bill & 0.0 & 0.0 & 10.8 & 0.5 & $\$ 2.5$ bill & & & \\
\hline$\$ 1 / 3$ bill & 0.0 & 0.0 & 10.8 & 1.0 & $\$ 5$ bill & $\$ 5$ bill & 9.6 & 2.4 \\
\hline$\$ 1 / 2$ bill & 0.0 & 0.0 & 10.8 & 1.6 & $\$ 7.5$ bill & & & \\
\hline$\$ 2 / 3$ bill & 0.0 & 0.0 & 10.8 & 2.1 & $\$ 10$ bill & $\$ 10$ bill & 9.6 & 4.7 \\
\hline$\$ 1$ bill & 12.0 & 2.2 & 4.9 & 1.4 & $\$ 15$ bill & $\$ 20$ bill & 25.9 & 25.7 \\
\hline$\$ 2$ bill & 12.0 & 4.4 & 7.7 & 4.5 & $\$ 30$ bill & & & \\
\hline \$3 bill & 12.0 & 6.6 & 7.7 & 6.7 & $\$ 45$ bill & $\$ 50$ bill & 5.2 & 12.6 \\
\hline$\$ 4$ bill & 12.0 & 8.8 & 7.7 & 8.9 & $\$ 60$ bill & & & \\
\hline$\$ 5$ bill & 12.0 & 11.0 & 6.5 & 9.4 & $\$ 75$ bill & & & \\
\hline$\$ 6$ bill & 12.0 & 13.2 & 6.5 & 11.3 & $\$ 90$ bill & & & \\
\hline$\$ 7$ bill & 12.0 & 15.4 & 6.5 & 13.2 & $\$ 105$ bill & $\$ 100$ bill & 10.4 & 52.3 \\
\hline \$8 bill & 12.0 & 17.7 & 6.5 & 15.1 & $\$ 120$ bill & & & \\
\hline$\$ 20$ bill & 1.0 & 3.9 & 0.0 & 0.0 & $\$ 300$ bill & & & \\
\hline \multirow[t]{2}{*}{$\$ 30$ bill } & 3.0 & 16.4 & 2.8 & 24.3 & $\$ 450$ bill & & & \\
\hline & $1 \overline{00.0 \%}$ & $\overline{100.0 \%}$ & $\overline{100.0 \%}$ & $\overline{100.0 \%}$ & & & $98.5 \%$ & $\overline{99.6 \%}$ \\
\hline
\end{tabular}

Sources and Notes: Grubb (2008, p. 286); JCC (v. 2, pp. 103, 105, 207; v. 3, pp. 398, 407, 457-8; v. 4, pp. 157, 164-5, 339-40, 374, 380-3; v. 5, pp. 599, 651); Newman (1997, pp. 58-63); Federal Reserve, http://www.federalreserve.gov/paymentsystems/coin/data.htm. U.S. currency today includes fractional dollars in the form of token coins that facilitate making change. No fractional dollar coins, actually no coins at all, were issued in Continental dollars. Thus, the currency pyramid contrast between current U.S. money and Continental dollar money is more accentuated than that presented in the table for just paper money.

a From http://eh.net "measuring worth—relative value of U.S. Dollars" using the 1790 to 1990 conversion algorithm. The Spanish silver dollar in 1790 and in 1775-76 was almost equivalent in value.

increasingly they could serve alone as a medium of exchange.

Early on, Congress may have hoped that the primary recipients of Continental dollars, namely soldiers, would hold their dollars for future redemption-basically hold them as bonds.

For example, on 6 August 1779, General Parsons explained,

I have not concerned myself with Commerce to increase my Estate Since the War... I...collected my dues [army salary] in Bills [Continental dollars] at their nominal Value in full Confidence...that at Some future Period my Country would do that Justice which they had promis'd me by paying their Debt at the nominal Value of the Bills they had emitted ...to render old age free from those miseries arising from Indigence... If my Country fails to Support her Independence, I shall be happy in possessing Nothing, but my Life. 
Soldiers’ pay absorbed nearly half of all Continental dollars emitted through 1777. Congress fixed the pay of soldiers on the same day (29 July 1775) that it passed the resolution establishing the Continental dollar's zero-interest bearer bond structure with fixed future redemption dates. A private was paid $\$ 80$ per year. Privates were the primary recipients of military pay, receiving 78 percent of the money paid to each military company. British army privates were paid $\$ 55$ per year. American privates were paid in paper Continental dollars, whereas British privates were paid in specie. In November 1775, the expected present value of 80 Continental dollars of the first emission was between $\$ 63$ and $\$ 53$, or comparable with the present value of a British private’s yearly pay. ${ }^{29}$ That Congress created the structural design of the Continental dollar on the same day in 1775 that it set the price of a private’s military pay, Congress' primary spending obligation, is telling. It is consistent with Congress using the expected present value rather than the face value of a Continental dollar to set military pay, thus acknowledging the zero-interest bearer bond nature of the Continental dollar it had just created.

The unconventional denominational structure of Continental dollar emissions is also consistent with Congress intending to pay soldiers in large bills that would be held for future redemption, rather than spent as currency. Throughout the American colonies, as well as in modern economies, currency denominations were typically spaced by factors of two, three, or five, and in a pyramid structure with more units in the lower than in the higher denominations. These features reduced the transaction costs of using that money as a medium of exchange in terms of making change. Table 3 shows that the denominational structure of the Continental

\footnotetext{
${ }^{29}$ Derived from Fortescue (1910-30, v. 4, pt. 2, p. 935); JCC (v. 2, pp. 89-90, 220-3; v. 3, pp. 322-3); Pennsylvania Gazette (14 August 1776); Smith (1978, v. 3, pp. 588-9); Williamson (1796, p. 27); and http://footguards.tripod.com/01ABOUT/01_payscale.htm [accessed 30 January 2013]. Currency conversions are from McCusker (1978, p. 10). Relative to privates’ pay, the pay of upper ranks increased less in the American than in the British army. Thus, by-rank comparisons above private are less informative. The Parson's quotation is from PCC (m247, reel 179, item 161, pp. 339-40) with the clauses slightly reordered to improve clarity. See also, Puls (2008, p. 187); Smith (1986, v. 13, p. 388).
} 
dollar did not have these features. ${ }^{30}$

The unusual denominational structure of the Continental dollar becomes sensible if Congress' intent was to pay soldiers in the fewest bills necessary, and thus in large-valued bills that were not intended to circulate easily as currency. Three months pay for a private, $\$ 20$, could be accommodated with one or various combinations of three, four, or five large-valued bills. One month’s pay for a private after clothing deductions, $\$ 5$, could be accommodated with one or various combinations of two large-valued bills. For higher ranked military personal, paying them with a few large-valued bills was even easier.

Soldiers’ pay was fixed by Congress in nominal terms in July 1775. As the war continued, the present value of soldiers’ pay when made in subsequent emissions fell. In November 1775, the expected present value of a full year's pay for an American private, when paid with dollars from the second emission, would be between $\$ 50$ and $\$ 41$-below the present value of a British private's yearly pay. For subsequent emissions, it was even lower. In effect, Congress was financing the war by extracting zero-interest borrowings from its citizen soldiers and increasingly so as the war progressed. This created problems for the financing system regarding military pay over a long war. Late in the war, Congress promised military personnel that Congress would make up "the deficiency of their original pay” when feasible. ${ }^{31}$ This promise is consistent with Congress acknowledging the zero-interest bearer bond design of the Continental dollar monetary system it had created, along with its declining present value as new emissions pushed redemption farther into the future.

After 1777, congressional payments for war supplies absorbed more Continental dollars

\footnotetext{
30 JCC (v. 2, pp. 220-3; v. 3, pp. 322-3); Newman (1997); Telser (1995); Van Hove (2001).

31 JCC (v. 15, p. 1335; v. 16, p. 344; v. 19, p. 413); Puls (2008, pp. 174-6, 181); Smith (1982, v. 9, p. 691; 1986 , v. 13, pp. 296, 414; 1988, v. 15, pp. 24, 29, 31).
} 
than soldiers' pay. ${ }^{32}$ When Congress spent Continental dollars in the marketplace for supplies and services, prices could be raised by suppliers and service providers to reflect the expected present value of the Continental dollars offered in payment. Suppliers and service providers were more likely to re-spend the money paid them because they had subcontractors and employees they had to pay. Figure 2 shows that market participants in Philadelphia did not start denominating transactions in dollar units, above that used prior to the first emission of Continental dollars, until sometime after mid-1776. By mid-1777, the public was pricing goods primarily in Continental dollars.

That Congress waited until 1777 to ask the states to make the Continental dollar a legal tender is consistent with this transition in usage. As war supplies came to dominate congressional spending, Continental dollars had to become a true transacting medium of exchange. This was difficult to achieve if Continental dollars with different emission dates had different contemporaneous expected present values. Legal tender laws eliminated this problem. The public could now think in terms of an expected average present value for any Continental dollar outstanding independent of the emission date on the bill. ${ }^{33}$

\section{DISCOUNTNG VERSUS DEPRECIATION, 1775-1779}

Table 2 and Figure 3 compare a Continental dollar’s expected average par present value with five reported measures of its purported “depreciation." Figure 3 uses the data in Table 2 to present a continuous picture of this comparison over time. It also extends the forecasted present

\footnotetext{
32 Grubb (2011, pp. 274-6).

33 See fn. 23. When Congress altered the redemption rules on 2 January 1779, they explicitly made the expected average present value of all Continental dollars identical regardless of emission date. A few market participants took notice. Edward Bonsall and Abraham Shoemaker advertised in the 27 January 1779 Pennsylvania Gazette that they would sell a tract of land "For Continental Currency of any date [italics in the original]." The implication of this previously unused phraseology is that prior to 2 January 1779 Continental dollars from different emissions may occasionally have been treated differently when settling accounts. Not all citizens may have understood that legal tender laws had already implicitly accomplished what the 2 January 1779 congressional resolution explicitly did. See also the Pennsylvania Gazette (10 and 17 February, 7 and 14 April 1779).
} 


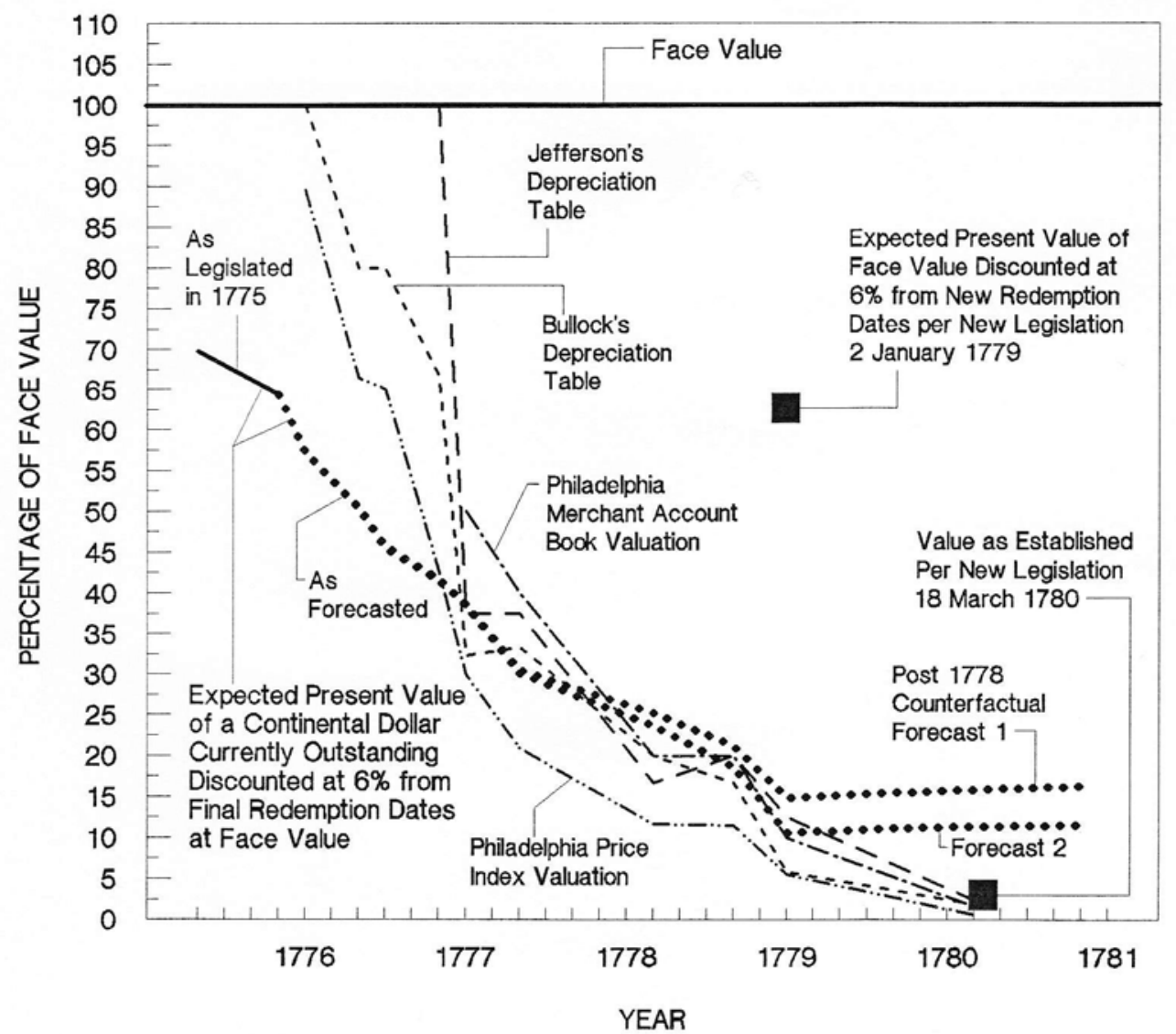

\title{
Figure 3 Expected Present Value of a Continental Dollar Currently Outstanding as a Percentage of its Face Value Discounted at 6 Percent from its Legislated and Forecasted Final Redemption Dates Versus Other Reported Measures of "Depreciation," 1775-1781
}

\begin{abstract}
Sources: Tables 1 and 2, Figure 1.
Notes: For discussions of expected present value calculations, interest rates, and legislated versus forecasted redemption dates, see Table 2 and the text. The present value time-path that would have proceeded from the 2 January 1779 solid square marker is not drawn because that face-value redemption path was neither credibly nor actually executed.
\end{abstract}

value estimates from January 1779 through November 1780 under the counterfactual presumption that the new redemption dates, legislated in January 1779, were not operative.

Finally, Figure 3 marks solid squares where the congressional legislative changes of 2 January 1779 and 18 March 1780 would have placed the ideal expected average par present value of a Continental dollar if redemption at face value was completed as these resolutions promised.

Between 1777 and 1779, the five reported measures of depreciation closely track the 
forecasted expected average par present value of a Continental dollar. Therefore, between 1777 and 1779, time-discounting, namely rational bond pricing, explains the current value of the average Continental dollar. In other words, little true depreciation of the Continental dollar occurred between 1777 and $1779 .{ }^{34}$ Of the five depreciation measures reported in Table 2 and shown in Figure 3 during these years, only the Philadelphia Price Index Valuation is noticeable below the forecasted expected average par present value of a Continental dollar. This may be due to Congress' removal from Philadelphia in early 1777 and the British occupation of Philadelphia between September 1777 and June 1778, which inflated prices in the Philadelphia region relatively more than elsewhere in the colonies during this period. ${ }^{35}$

Before 1777, all five reported depreciation measures in Figure 3 are above the expected average par present value calculations. This is puzzling. Before 1777, either the marketplace did not understand time-discounting, patriotic fervor trumped economic interests, or the reported depreciation measures pre-1777 are suspect. The latter is the case. The first reports of Continental dollars trading below face value appeared before Congress in Philadelphia on 23 November 1775, long before the conventional measures of depreciation in the literature record it. This event occurred immediately after the structural design of the Continental dollar was first reported in Pennsylvania newspapers. After the public was told that Continental dollars were zero-interest bearer bonds with defined maturity dates, they started to accept them below their face value. This “depreciation” was discussed in Congress and in the newspapers through 1776. As such, the conventional measures of depreciation shown in Figure 3 and Table 2 understate the

\footnotetext{
34 On 20 December 1776 Robert Morris valued a Continental dollar at 50 percent, on 30 September 1777 William Williams valued it at 25 percent, on 9 March 1778 the Committee at Camp valued it at 25 percent, and on 19 July 1779 the Commerce Committee valued it at 16.7 percent of its face value (Smith 1979, v. 5, p. 623; 1981, v. 8, p. 35; 1982, v. 9, p. 245; 1986, v. 13, p. 257). These evaluations are about 9, 3, 0, and -3 percentage points closer to face value than the forecasted expected average par present value estimated in Table 2 and Figure 3, respectively.

${ }^{35}$ See Smith (1980, v. 6, p. 213; 1981, v. 8, p. 376).
} 
extent that Continental dollars traded below their face value before $1777 .^{36}$

Congress reacted to these reports of depreciation by referring the issue to committees and publishing admonishments against such behavior. Through 1776, however, these admonishments only condemned the refusal to accept Continental dollars, not its acceptance below face value. Benjamin Franklin was in Congress. He had long known that the present value of a zero-interest bearer bond was below its face value. He had argued in Congress, unsuccessfully, for the Continental dollar to pay interest, because such would raise its present value to be closer to its face value in contemporaneous trades. As long as Franklin was in Congress, while some railed against depreciation as an evil and unpatriotic act, resolutions condemning depreciation, as opposed to just condemning non-acceptance, did not pass. Perhaps Franklin was able to convince some congressmen that time-discounting was not depreciation. ${ }^{37}$

The price index evidence in Table 2 and Figure 3 does not reflect market pricing in Continental dollars until after 1776. The price index comes from merchant account books. In these books, merchants converted market transactions from whatever media of exchange were used into a common unit of account, namely into pounds, shillings, and pence of Pennsylvania money. For transactions in dollars, merchants used a fixed conversion rate of $\$ 1=7$ shillings, 6 pence. Only when prices in the marketplace were typically transacted in dollars would the price index reflect the value of dollars in the marketplace rather than the value of some other media of

${ }^{36}$ JCC (v. 3, pp. 367-8, 424, 455; v. 4, pp. 49-50, 293-4, 381-3; v. 5, pp. 608, 724-8; v. 6, p. 1046); Pennsylvania Gazette (17 January; 17 and 24 April; 19 June 1776); Smith (1977, v. 2, p. 464; 1978, v. 3, pp. 83, 255; 1979, v. 5, pp. 295, 424, 439-40, 570, 623, 639, 678).

37 See fn. 36; Labaree (1967, v. 11, pp. 7-18; 1970, v. 14, pp. 35-8); JCC (v. 3, pp. 367-8; v. 4, p. 49); Oberg (1992, v. 29, pp. 354-6); Smith (1978, v. 3, pp. 83, 90). Congress appointed Franklin commissioner to France on 26 September 1776 (JCC v. 5, p. 827). For other examples of colonial writers articulating the time-discounting embedded in the structure of colonial bearer-bond paper monies, see Davis (1964, v. 1, pp. 384-5v. 2, pp. 314, 318; v. 3, pp. 158-9, 182, 191, 196-8, 247, 430-1, 433, 440, 445, 454, 462, 471; v. 4, pp. 49, 179-80, 185, 223, 386, 398, 401-2). Pelatiah Webster, an influential contemporary writer, also understood the impact of time-discounting. In an essay published in the Pennsylvania Evening Post, 5 October 1775, he asked in reference to the Continental dollar, "Why should the soldier...be paid in promises, which are not so good as money, if fulfilment is at a distance?" (Webster 1969, pp. 1-2). 
exchange. Figure 2 shows that market prices before 1777 were not expressed in dollar units beyond that used prior to the first emission of Continental dollars. As such, the price index does not reflect movements in the value of Continental dollars pre-1777. After 1776, dollar usage rose to dominate marketplace transactions. Thus, after 1776 the price index reflects movements in the value of Continental dollars. $^{38}$

The depreciation tables under the Jefferson and Bullock headings in Table 2 and Figure 3 were created well after the fact, mostly in the early 1780s. How they were created, upon what evidence they were based, and whether they were intended to measure the current present value of Continental dollars is seldom noted. Their purpose was to establish the principal to be repaid on congressional borrowings of Continental dollars via loan office certificates. Was the principal to be repaid the present value at the time of borrowing or the face value? The first depreciation table was recorded in Congress on 28 June 1780. It computed “a progressive rate of depreciation...in geometrical proportion to the time” starting at face value and running to 18 March 1780. The starting point was when Congress first borrowed Continental dollars-late 1776 into early 1777. Thus, by construction, these depreciation tables overstate the present value of Continental dollars before $1777 .^{39}$

Beginning in early 1779, the five reported measures of depreciation depart from the

\footnotetext{
38 Bezanson (1951, pp. 1-11, 25, 332-42). John Adams indicated on 12 October 1775 that Continental dollars were not yet in general circulation (JCC v. 3, p. 491). The evidence in Figure 2 comes from the same market, but is different than that used to construct the price index. That dollar statements in Figure 2 post-1776 are primarily referring to Continental dollars can be inferred from the rise in the nominal sums offered for the same activities between early 1775 and post-1777 to 1781. The Philadelphia Merchant Account Book Valuation of depreciation in Table 2 and Figure 3 uses a single account book with questionable assumptions about how to separate war effects from depreciation pre-1777.

39 Boyd (1954, v. 10, pp. 42-3); JCC (v. 5, pp. 845-6, 850; v. 6, pp. 949, 955-6; v. 7, pp. 36, 143, 225; v. 8, p. 578; v. 9. p. 955; v. 17, pp. 567-8); Oberg (1998, v. 34, pp. 231-2); Pennsylvania Gazette (19 July 1780); Smith (1979, v. 5, pp. 307-8, 349, 470, 623, 639; 1988, v. 15, pp. 49-50, 377, 384). Some writers thought that approximately 30 million dollars were required to transact commerce (JCC v. 15, p. 1054; Smith 1986, v. 13, pp. 495, 532; Webster 1969, p. 6). They assumed that no depreciation could occur until that sum was exceeded. Continental dollars did not exceed 30 million until May 1777. Jefferson's table shows depreciation only after May 1777. As such, he may have simply assumed that no depreciation was possible before that date.
} 
forecasted expected average par present value of a Continental dollar, falling increasingly below these forecasts through early 1780. On 2 January 1779, Congress altered the redemption structure of all past and future Continental dollars, see Table 1. If Continental dollars would have been redeemed at face value as established in this resolution, then the expected average par present value of a Continental dollar in January of 1779 would have been reset at 62 percent of face value. Yet, all five reported measures of depreciation in early 1779 continue to decline, from an average of 9 percent to 2 percent of face value by early 1780. Even if this new January 1779 legislation is ignored and Forecasts 1 and 2 are used instead as counterfactual measures of the expected average par present value of a Continental dollar, the reported measures of depreciation fall increasingly below these counterfactuals by at least 10 percentage points by early 1780 .

Finally, on 18 March 1780, Congress altered the redemption path of all outstanding Continental dollars, asking that all be redeemed within 13 months, see Table 2. If they were all to be redeemed at face value over these 13 months that would have pushed the expected average par present value of a Continental dollar to its face value in 1780-81. However, in this legislation Congress allowed states to be credited when filling their remittance quotas at a rate of 40 Continental dollars equaling 1 Spanish silver dollar. Congress held to this rate for crediting state remittances to the national treasury through 1789. In addition, two days later, on 20 March 1780, Congress recommended that the states remove the Continental dollar's legal tender status in their jurisdictions, which the states quickly did. Continental dollars could now be redeemed at rates other than face value. As such, expected present value calculations of a current Continental dollar become precarious because redemption value at maturity is no longer anchored, or guaranteed to be, at face value. ${ }^{40}$

${ }^{40}$ See fns. 26 and 50; Grubb (2012a, p. 155); JCC (v. 16, p. 269); Mevers (1979, p. 280). 
As Figure 3 shows, the 40 to 1 rate for crediting state remittances enacted in March 1780 is both well below face value and at least 10 percentage points below the counterfactual Forecast 1 and 2 estimates of expected average par present value. The five reported measures of depreciation in Table 2 and Figure 3 more or less converge on that 40 to 1 rate (or to slightly below that rate) from early 1779 to early 1780 . The collapse of the Continental dollar finance system began in January 1779 and accelerated thereafter. How that collapse unfolded is addressed next.

\section{THE COLLAPSE OF CREDIBLE COMMITMENT, 1779-1790}

By 1778, Congress faced a dilemma. The redemption dates of new emissions, using either Forecast 1 or Forecast 2 in Table 2 and Figure 3, were so far in the future that new emissions had little current present value. The redemption of new emissions could no longer be pushed successively into the future. Redemption had to be pulled closer to the present. Doing so would cause redemption intervals for prior and future emissions to overlap which, in turn, would necessitate capping total emissions to maintain fiscal credibility. In 1779 and 1780, Congress attempted to resolve this dilemma. In the process, their actions forced depreciation onto the Continental dollar and precipitated the collapse of the monetary system.

On 2 January 1779, Congress changed redemption requirements for the Continental dollar. All the structural procedures from 1775 were kept in place except the installment amounts and contiguous-year redemption intervals. ${ }^{41}$ In addition, all past and future emissions were to be treated equally, see Tables 1 and 2. The states were now to redeem 15 million in 1779 and an equal amount each year through 1797, the amount needed to exhaust the remainder. ${ }^{42}$ While this

\footnotetext{
${ }^{41}$ The specie redemption option for citizens at the Continental treasury was not mentioned in the 2 January 1779 resolution. However, Congress indicated that it was still operative on 14 June 1779 (JCC v. 14, p. 728).

42 JCC (v. 13, pp. 20-1). The 2 and 14 January 1779 congressional resolutions on paper money were reprinted in the Pennsylvania Gazette on 27 January 1779.
} 
resolution filled in the missing redemption instructions for the eight preceding emissions, it also altered the redemption pattern set in the first two emissions passed by Congress in 1775 . As such, the expectations built into Forecasts 1 and 2 were no longer valid.

On 1 September 1779, Congress set a \$200 million limit for total net new emissions. This limit was reached on 29 November $1779 .{ }^{43}$ Thus, by the end of 1779 the states were required to remit 10,277,778 Continental Dollars each year from 1780 through 1797 to the Continental treasury to be burned. Eighteen years times 10,277,778 plus 15,000,000 for 1779 equaled 200 million Continental Dollars. The tax implications of this change placed it beyond what was feasible, or historically acceptable, if Continental Dollars were taken at face value. The tax per white-capita per year for the 2 January 1779 redemption structure was $\$ 6.95$ for 1779 and then $\$ 4.65$ for 1780 falling continuously to $\$ 2.59$ by 1797 (due to population growth). ${ }^{44}$ These tax levels were 8 to 21 times higher than the feasible, or historically acceptable, level of $\$ 0.33$.

On 18 March 1780, Congress changed redemption requirements again. States were to redeem 15 million Continental dollars each month over the next 13 months. Thirteen months times 15 million equaled 195 million or 97.5 percent of the Continental dollars ever emitted. The remaining 5 million were due in the future from Georgia which having been invaded was temporarily exempt from sending remittances. The states were also allowed to substitute one Spanish silver dollar in lieu of 40 Continental dollars when filling their quotas. The 18 March 1780 resolution did not remove the option citizens had to redeem their Continental dollars directly at the Continental treasury for their face value in specie, as stated in the 29 July and 26

\footnotetext{
43 Grubb (2008, 2012a); JCC (v. 14, pp. 1013-4; v. 15, pp. 1019, 1053, 1171, 1324).

44 That the public and Congress were concerned about the fiscal credibility of these changes is revealed in the frontpage editorial in the Pennsylvania Gazette, 19 May 1779, and in the address to the public by John Jay, President of Congress, 13 September 1779 (JCC v. 15, pp. 1051-62; Pennsylvania Gazette, 29 September 1779). See also Smith (1985, v. 11, pp. 361-2; 1989, v. 16, pp. 485-98); Sumner (1968, v. 2, pp. 76-7); and fn. 46.
} 
December 1775 resolutions and in congressional discussions on 14 June $1779 .{ }^{45}$ The tax implications of this change placed it well beyond what was the feasible, or historically acceptable, tax level of $\$ 0.33$. If Continental dollars were taken at face value, the tax per whitecapita per year would be $\$ 86.72$ for 1780 or 263 times above the normal tax level. If using the 40 to 1 specie substitution rate, it would still be $\$ 2.17$ or 6.6 times above the normal tax level.

The 2 January 1779 and 18 March 1780 congressional resolutions had some good consequences. Congress reassured the public that the basic design of the Continental dollar was that which the public had been told in 1775. The Continental dollar was a zero-interest bearer bond with fixed future redemption dates. It was to be redeemed through state taxes by those dates or exchanged by citizens at the national treasury for specie at its face value after those dates. By applying the same redemption interval to all Continental dollars—past, present, and future-the 2 January 1779 and 18 March 1780 resolutions also directly and more formally solved the problem of Continental dollars from different emissions trading contemporaneously at different present values compared with how legal tender laws solved this problem.

Two bad consequences, however, came with the 2 January 1779 and 18 March 1780 resolutions. First, by changing the redemption dates of past emissions, Congress was passing ex post facto laws. This created the possibility that Congress could change the present value of its debt obligations at will, thus increasing the uncertainty and risk in holding these obligations. Second, the 2 January 1779 and 18 March 1780 resolutions established redemption procedures that were not fiscally credible, see Table 2 . To meet the redemption schedules imposed on the states in 1779 and 1780, or the schedule the states actually did meet in the 1780s, taxes per white-capita per year had to be well above what had been historically acceptable, and/or states

\footnotetext{
45 Ferguson, et al. (1973, v. 1, p. 194); JCC (v. 14, p. 728; v. 16, pp. 262-7). This act was reprinted in the Pennsylvania Gazette on 29 March 1780.
} 
had to acquire Continental dollars at substantially depreciated values. ${ }^{46}$

The two years when the states remitted the most Continental dollars to the national treasury were 1781 and 1782, namely \$53,690,923 and \$24,506,561 in face value, respectively. ${ }^{47}$ The per white-capita per year taxes needed to raise these two sums, if Continental dollars were to be retired at face value, were 56.8 and 24.9 times higher than the average per white-capita per year tax of \$0.41 in the colonies for all taxes levied between 1770 and 1774, and 70.5 and 30.9 higher than that established in 1775 (\$0.33) for retiring Continental dollars, respectively. (We are not talking about raising taxes by 20 percent or 50 percent or even 100 percent, but by multiple factors or by hundreds if not thousands of percent.) Anyone could see that such tax levels were not feasible and so not credible. As such, everyone had to know that these new plans entailed redemption not at face value but at depreciated values, and hence a destruction of the Continental dollar monetary system as initially designed.

Figure 4 presents the tax implications of Congress' change in redemption policy in 1779 and in 1780 . It sets the feasible, or historically acceptable, tax level of $\$ 0.33$ per year per whitecapita at zero. It then calculates the multiple factor increase in that tax level needed to accommodate the new legislation of 2 January 1779 and 18 March 1780 if Continental dollars were redeemed at face value and, alternatively, if Continental dollars were redeemed at their current expected average par present value as estimated using counterfactual Forecasts 1 and 2.

Figure 4 shows that the new redemption resolutions of 1779 and 1780 exploded the tax level for redemption at face value, peaking at near 22 times normal in 1779 for the 1779 resolution and at 263 times normal in 1781 for the 1780 resolution. If the 1780 resolution is

\footnotetext{
46 See fn. 44; Smith (1985, v. 11, pp. 361-2, 370-1, 406; v. 12, p. 236; 1986, v. 13, pp. 24, 85-6, 90-1, 388, 524-5, 529-33, 603-4; 1987, v. 14, pp. 41-2, 50, 241, 286, 288-90, 292, 298, 437, 452; 1988, v. 15, pp. 89-90, 140, 405, 490, 628; 1989, v. 16, pp. 127, 192, 286, 506, 641; 1990, v. 17, pp. 34-5, 49, 128, 150, 192, 212-3, 363).

47 See Grubb (2012a, pp. 164, 169-73).
} 


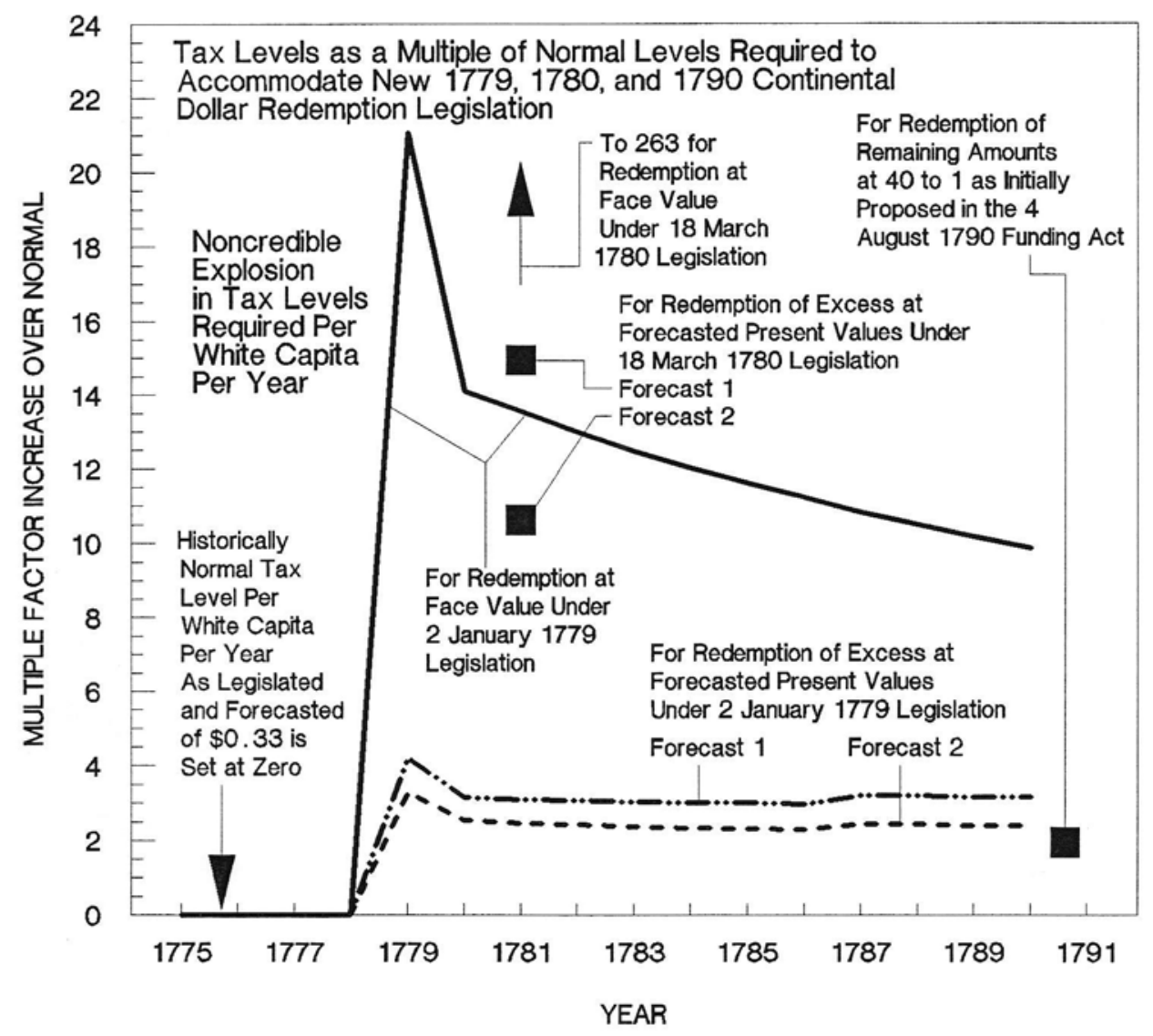

Figure 4 Tax Levels Needed to Accommodate New Continental Dollar Redemption Legislation, 1779, 1780, and 1790 as a Multiple of Normal Levels

Sources: Tables 1 and 2, Figure 3.

Notes: For discussion of construction, see the notes to Tables 1 and 2, Figure 3, and the text.

ignored and states are assumed to have followed the redemption structure in the 2 January 1779 resolution, which in fact as a group the states basically did, then redemption at face value between 1780 and 1790 would still entail tax levels between 10 and 14 times normal. ${ }^{48}$ Being fiscally impossible, Congress’ commitment to face-value redemption lacked credibility.

The taxes to redeem Continental dollars could not be used to support the war or re-spent in any way. The bills so redeemed were burnt. Congress reached its self-imposed limit of new emissions in November of 1779. Thus, current war expenses, as well as the regular costs of

\footnotetext{
48 See Grubb (2012a, pp. 162-4).
} 
government, could no longer be met with new emissions. Loans and "expenditure" taxes were the only alternative means. On 27 June 1780, Congress' Board of Treasury reported that “...the Treasury of the United States...[is] totally exhausted.” They reported that the “...Continental Loan offices in the respective States, have received but very little money...” Expenditure taxes requested from the states for 1778,1779 , and the first two months of 1780 were in arrears. The Board reported that the balances due were $\$ 45,523,461 .{ }^{49}$ These were taxes on top of the taxes to redeem Continental dollars. These tax arrears amounted to $\$ 20.60$ per white-capita or 50 times greater than the per white-capita per year tax level $[\$ 0.41]$ in the colonies for all taxes levied between 1770 and 1774 . Adding these expenditure taxes to the taxes for redeeming Continental dollars pushed per white-capita per year tax levels beyond comprehension. The fiscal impossibility of what Congress did in 1779 and 1780 regarding redeeming Continental dollars was compounded by the fiscal impossibility of the expenditure taxes Congress requested on top of the taxes required to redeem Continental dollars. Something had to give, and that was the credibility of Congress' commitment to the Continental dollar monetary system.

The policy changes enacted by Congress in 1779 and 1780 regarding Continental dollar redemption appeared to be intentionally destructive of the Continental dollar monetary system in that they were wildly beyond feasible, or historically acceptable, tax levels. Everyone could see this. The policy changes seem so crazy that perhaps Congress had something else in mind that was more sensible and legitimate than redemption at face value, namely redemption at current expected average par present value. If Congress simply planned to have states buy up the excess Continental dollars at their current expected par present value and remove them from circulation, then no depreciation or loss in true value would follow. Congress would have ended the

49 JCC (v. 17, pp. 563-4). See also Smith (1990, v. 17, p. 363). 
Continental dollar episode without loss of credibility and without defaulting on its obligations.

Figure 4, however, shows that even if Congress intended in its new legislation of 1779 and 1780 to redeem Continental dollars at their current expected average par present value, the tax levels needed to accomplish this were still multiple factors above normal. Using the counterfactual Forecasts 1 and 2 to measure current expected average par present values of Continental dollars, Figure 4 shows that redemption at those values under the 1780 resolution would require tax levels 11 to 15 times above normal, and under the 1779 resolution would require tax levels 3 to 4 times above normal. Even if the redemption rate is taken as the 40 to 1 rate set in 1780 and maintained to 1790 for crediting state remittances, the tax level needed to redeem or buy up all Continental dollars still outstanding in 1790 at that rate would be almost 2 times above normal. ${ }^{50}$ These are tax level separate from any expenditure taxes requested. Congress' actions in 1779 and 1780 forced true depreciation on the Continental dollar and destroyed that monetary system. When states set the specie value of new taxes impossibly high then, barring tax revolts, citizens had to liquidate goods, land, and bonds (Continental dollars) to acquire the specie needed to meet these new taxes, thereby driving down the specie price of goods, land, and bonds. As such, Continental dollars would trade for specie at rates below their current par present value, namely at depreciated rates. The states could now accept Continental dollars for tax payments at these depreciated rates rather than at their average par present value (at their face value for those reaching maturity). In the 1780s, the U.S. experienced deflation in the specie value of goods and land, as well as tax revolts related to this deflation. State efforts to comply with congressional changes in the redemption of Continental dollars

50 See Archives of Maryland (v. 43, pp. 258-9); Bolles (1969, v. 1, pp. 97-8, 135-6); Boyd (1953, v. 7, pp. 221-3); Bullock (1895, pp. 136-8; 1900, p. 72); Elliot (1843, pp. 77-82); Ferguson, et al. (1975, v. 2, pp. 70-1); Grubb (2012a, pp. 160-1); JCC (v. 16, pp. 165, 217, 253, 262-7, 269; v. 23, pp. 560-1, 590); Phillips (1866, pp. 160-6); Sumner (1968, v. 1, pp. 87-9); Webster (1969, p. 111). See also Smith (1981, v. 8, p. 366; 1985, v. 11, pp. 306-7, 382; 1986, v. 13, pp. 351-2, 388, 603-4; 1987, v. 14, pp. 463-4, 500, 506, 514, 519-32). 
contributed to this post-war depression. ${ }^{51}$

The 2 January 1779 and 18 March 1780 resolutions forced depreciation beyond timediscounting onto the Continental dollar. The only way a state could redeem Continental dollars in the amounts required by these resolutions was to acquire them at depreciated values. A state could not effectively do this without enacting tax codes that violated the legal tender equivalence between specie and Continental dollars in state law for paying state obligations. On 20 March 1780 Congress recommended that the states revoke the Continental dollar's legal tender status in state law. From late 1780 through mid-1781 the states complied. The Continental dollar monetary system collapsed shortly thereafter. ${ }^{52}$

Figure 5 presents estimates of the "true" depreciation of the Continental dollar from 1775 through 1790. This depreciation is measured as a percentage reduction below the forecasted expected average par present value. Figure 5 sets the expected average par present value at 100, using actual values from 1775 and the average of Forecasts 1 and 2 for years after 1775, see Table 2. The average of the five measures of reported depreciation in Table 2 as a percentage of this expected average par present value is then graphed as the true depreciation.

Before 1777, the depreciation measures are above the present value estimates and so no true depreciation exists. Between 1777 and 1779 some minor depreciation beyond timediscounting appears. At its worst, depreciation represented about 76 percent of the expected average par present value in early 1778. Otherwise it was in the 85 to 95 percent range of the expected average par present value during these years. Not only is this depreciation minor compared with what was to come starting in 1779, but the magnitude is questionable. Almost all

\footnotetext{
51 See Holton (2007); Smith (1990, v. 17, pp. 401, 462). Alternatively, this outcome could be described as new state taxes forcing citizens to discount Continental dollars at rates well above the market rate of 6 percent which, in turn, reduced their current present value below their true par present value.

52 See fn. 26; Smith (1986, v. 13, p. 129).
} 


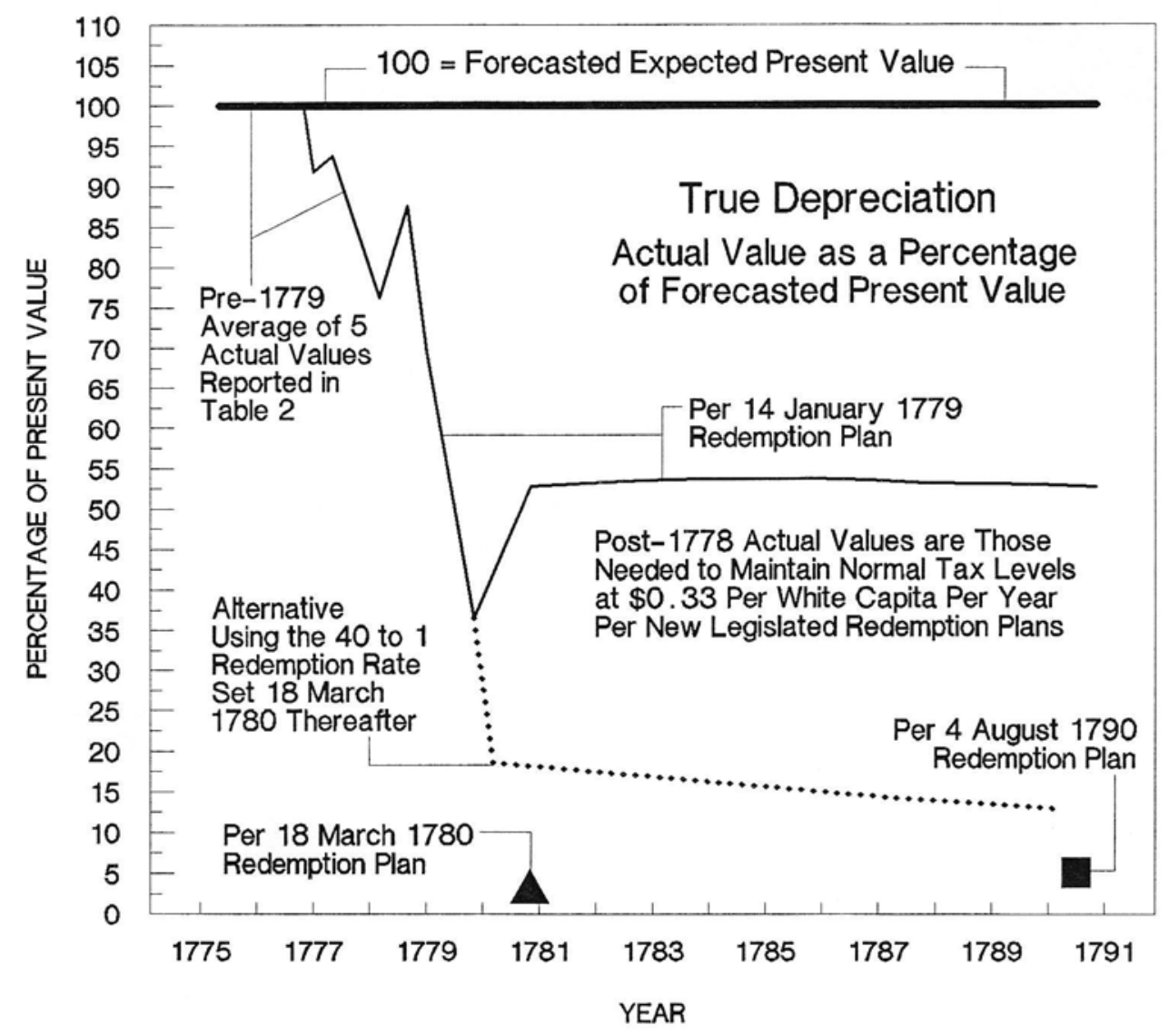

Figure 5 True Depreciation of the Continental Dollar, 1775-1790

Sources: Derived from data and sources reported in Tables 1 and 2, Figure 3, and the text.

Notes: See the text for discussion of construction. From 1779 to 1790 the average of counterfactual Forecasts 1 and 2 are used. Depreciation between 1777 and 1779 is dominated by the Philadelphia Price Index measure of depreciation. If that measure is removed from the average of the five depreciation measures reported in Table 2, then almost no true depreciation would be reported for these years.

of the depreciation in Figure 5 between 1777 and 1779 is driven by only one of the five reported measures of depreciation in Table 2, namely the Philadelphia Price Index Valuation. This Index may bias depreciation to be greater than it really was in early 1777 because of the removal of Congress to Baltimore, and between September 1777 and June 1778 because the British occupation of Philadelphia in this period may have inflated prices in the Philadelphia region relatively more than elsewhere in the colonies during this period. ${ }^{53}$

53 See Smith (1980, v. 6, p. 213). 
Nevertheless, three conditions conducive to some depreciation from 1777 to 1779 were present. First, legal tender laws passed in early 1777 caused the present value of prior emissions to be affected adversely by subsequent emissions, see Figure 1 . By merging the redemption window of a new emission, which would be farther in the future than that of all prior emissions, with the redemption windows of all prior emissions, legal tender laws effectively elongated the redemption window of all prior emissions, thus lowering their expected average par present value. Forecasts of the likelihood of future emissions would then lead to a fall today in the expected average par present value of emissions currently outstanding. Second, Table 2 shows that by mid-1777 using Forecast 1 average per year per white-capita tax levels needed to support redemption at face value began to creep above historically normal levels, by 30 to 50 percent by mid-1778. This fiscal pressure may have caused some concern about the credibility of Congress' commitment to future redemption as forecasted. Third, the emissions of mid-1777 and mid-1778 (emissions \#8 and \#9) were under serious threat of being counterfeited by the British. Congress moved on 2 January 1779 to solve this problem by swapping all genuine bills from emissions \#8 and \#9 for new bills from emission \#11. Prior to this solution, some concern over this counterfeiting may have increased depreciation in the mid-1777 to mid-1778 period. ${ }^{54}$ By January 1779, however, true depreciation stood at only 87 percent of expected average par present value (see Figure 5).

The continuous depreciation measures reported in the literature stop in 1781 (see Table 2 and Figure 3). Several alternatives are used in their place to have a number to divide into the forecasted expected average par present value to get the true depreciation measures shown in Figure 5. The first takes the redemption plan of 14 January 1779 and asks what the depreciation

54 See Grubb (2012a, pp. 153-4, 157-60, 163); JCC (v. 9, p. 1037; v. 12, pp. 1073, 1224); Smith (1981, v. 8, pp. 659, 695; 1982, v. 9, p. 284; 1983, v. 10, p. 202; 1985, v. 11, pp. 347, 392, 410; v. 12, pp. 24-5; 1986, v. 13, p. 3512). 
rate below expected average par present value would have to be to maintain a normal tax level of $\$ 0.33$ per year per white-capita to successfully execute the redemption amounts as legislated. The second assumes that the redemption rate of 40 Continental dollars per 1 Spanish silver dollar set on 18 March 1780 by Congress for crediting state remittances to the national treasury held as the depreciation rate through 1790 . Its percentage of the expected average par present value each year is then graphed in Figure 5. Finally, solid markers are placed in Figure 5 to indicate what the depreciation rate below expected average par present value would have to be to maintain a normal tax level of $\$ 0.33$ per year per white-capita to successfully execute the redemption amounts as legislated on 18 March 1780 and on 4 August 1790. These last two resolutions were designed to be complete redemptions in a single year.

Figure 5 shows that beginning in early 1779, depreciation jumps to at best 53 percent and at worst 3 percent of expected average par present value by 1781, never improving from those levels between 1781 and 1790. This was a colossal collapse in real present value from that forecasted. Not surprising, given the analysis here, markets in Continental dollars disappeared in $1781 .^{55}$ It is hard to avoid the conclusion that Congress crashed a cumbersome but otherwise viable monetary system with its resolutions of 2 January 1779 and 18 March 1780.

Other explanations of the time path of depreciation as measured in Figure 5, such as war news, do not fare as well as the explanations linked to the formal changes to the redemption tax structure. ${ }^{56}$ For example, major military and political defeats of the Americans early in the war, before 1777, are not associated with Continental dollar depreciation below expected average par present value as might be expected. By contrast, good military and political news for the United States from 1777 onward, with the exception of a minor reduction in depreciation in mid-1778, is

\footnotetext{
55 See fn. 26; Smith (1989, v. 16, pp. 543-4; 1990, v. 17, pp. 49-50, 64, 76, 90, 124, 128, 150, 179-80, 212, 215, 218-20, 222-4, 228, 236, 241, 243-4, 251, 256, 350, 401, 432, 462, 536).

${ }^{56}$ For an alternative assessment, see Calomiris (1988, pp. 56, 61).
} 
not associated with any significant appreciation of the Continental dollar as might be expected, see Figure 5. For example, the victories in the Battles of Trenton and Princeton from December 1776 into January 1777, victory in the Battle of Saratoga in October of 1777, French entry into war in 1778 on the American side, the British withdrawal from Philadelphia in mid-1778, Spanish entry into the war in 1779 on the American side, Dutch entry into the war in 1780 on the American side, and victory at the Battle of Yorktown in October of 1781 explain little. The credibility of future redemption at face value rested primarily on whether redemption taxes were legislatively set at feasible levels and not on war news per se.

\section{CONCLUSION}

For 235 years we have been told a myth, namely that the Continental dollar was created by Congress as a pure fiat currency, that it rapidly depreciated after being issued with excessive emissions soon making it worthless, and that this folly led the founding fathers in 1787 to take the power to issue such fiat currency away from Congress in the new U.S. Constitution. This mythic narrative has reigned unchallenged for 235 years because it is an easy, pleasing, and convenient perspective that fits particular prejudices regarding money. The absurdity of this myth is seldom considered. How a voluntary extra-legal body with no sovereignty and no power of coercion could issue a pure fiat currency that had any value, and why any one in Congress would have been so irrational as to think that they could do so, has never been addressed.

It is time for a new perspective of the Continental dollar—one that better aligns with the historical record and rational behaviors. The Continental dollar was not a pure fiat currency, but a zero-interest bearer bond. It had defined redemption structures set credibly into the future, i.e. within plausible tax levels, and rested on the states' sovereign power to coerce taxes as agreed to by the respective states' appointed representatives to Congress. Early on, the states actually 
redeemed the Continental dollar in the amounts as initially legislated. ${ }^{57}$ The resolutions of Congress (the law) tell us the Continental dollar was a zero-interest bearer bond. The distinct language printed on the face of the bills tells us the Continental dollar was a zero-interest bearer bond. The initial legislated pay of soldiers is consistent with the Continental dollar being a zerointerest bearer bond. The denominational structure of emissions is consistent with Continental dollars being zero-interest bearer bonds. The behavior of the public immediately after being told about the Continental dollar's redemption structure is consistent with it being treated as a zerointerest bearer bond. The present value of Continental dollars compared with reported measures of depreciation from 1777 to 1779 is consistent with Continental dollars being zero-interest bearer bonds. These facts are ignored by the traditional narrative.

If the Continental dollar was a zero-interest bearer bond, then time-discounting must be considered when assessing its present value. That present value indicates that little depreciation beyond time-discounting existed prior to 1779. On 2 January 1779 and 18 March 1780, Congress altered the redemption (maturity) dates of Continental dollars in an ex post facto way that was not fiscally feasible, and so not credible. These actions, by necessitating massive depreciation beyond time-discounting, crashed a cumbersome but otherwise viable monetary system.

Two questions remain. First, did congressmen know what they were doing in 1779 and 1780? Was it intentional, and then covered up with rhetorical machinations (the ubiquitous retelling of the traditional story), or was it a product of ignorance, confusion, and mismanagement by otherwise well-meaning individuals? Second, could Congress have done otherwise? Was there a fiscally credible strategy to redeem Continental dollars at face value as initially designed and reasonably forecasted, and if so what were the costs and benefits of such a

${ }^{57}$ See Grubb (2012a). 
strategy? The answers to these questions are taken up in the next two chapters.

Finally, the history of the Continental dollar shaped the debates and decisions at the 1787

Constitutional Convention regarding monetary powers in the new U.S. Constitution. The

delegates offered only general statements about “mischiefs” that caused “disgust” with paper

money. The analysis here suggests that these mischiefs may not have been what many

subsequent scholars, and perhaps many founding fathers, thought they were. The true mischiefs

were the passage of ex post facto laws in 1779 and 1780 that changed the redemption dates of

Continental dollars, and hence their present value, in ways that were not fiscally credible in

terms of retiring Continental dollars at face value. Could the founding fathers have solved the

monetary problems arising from such congressional behavior by some structural change in the

new U.S. Constitution other than insisting on an absolute prohibition on paper money

emissions? ${ }^{58}$ The answer to this final question will be addressed in the last chapter.

\footnotetext{
58 If a Continental dollar, as the quintessential bill of credit, is viewed as a zero-interest bearer bond, then prohibiting Congress from issuing bills of credit but allowing Congress "to borrow money on the credit of the United States" (Article 1, Section 8; Farrand 1966, v. 2, pp. 308-10) seems contradictory. A zero-interest bearer bond is after all a bond, i.e. a borrowing. The difference is not in whether a bond pays interest or not, but in how purchasing was exercised by Congress. Bills of credit were used by Congress to directly purchase goods and services in a hand-to-hand money-like exchange. Borrowing money on the credit of the United States, at that time, entailed selling bonds in the marketplace for real money, namely gold and silver monies, which would then be used by Congress to directly purchase goods and services. Congress' ability to borrow in the marketplace was constrained by the interest rate they had to offer to obtain the real money required, something that did not factor into the direct purchase of goods and services using bills of credit. If congressional purchases were directly made using bills of credit, then goods and services would gravitate toward being priced in the marketplace in bills of credit. Whereas, if congressional purchases were made indirectly using bonds that were first sold for gold and silver monies, then goods and services in the marketplace would remain priced in those gold and silver monies. It is this distinction, or layer of separation, that distinguishes the direct spending using bills of credit as a bond-like instrument from more traditional borrowing using the commonly understood government bond. By this understanding, the founding fathers could be seen as trying to discipline Congress by forcing Congress to face the discipline of the marketplace, in terms of interest-rate pricing of its bonds, when spending more than it had in revenue. This was a discipline that lacked in immediate severity if Congress used bills of credit to meet revenue shortfalls. They could also be seen as wanting to make sure that pricing in the marketplace stayed in gold and silver monies, and would not gravitate toward pricing in some other paper money unit.
} 


\section{References}

Acts of the council and general assembly of New-Jersey. 1784. Trenton, NJ.

Archives of Maryland, vols. 1-72. 1883-1972. Baltimore, MD: Maryland Historical Society.

Baack, Ben 2001. 'Forging a nation state: the Continental Congress and the financing of the War of American Independence', Economic History Review 54: 639-56.

2008. 'America’s first monetary policy: inflation and seigniorage during the Revolutionary War’, Financial History Review 15: 107-21.

Bezanson, Anne 1951. Prices and inflation during the American Revolution: Pennsylvania, 1770-1790. Philadelphia: University of Pennsylvania Press.

Bolles, Albert S. 1969. The financial history of the United States from 1774 to 1789, vols.1-3. New York: Augustus M. Kelly, [original 1884].

Boyd, Julian P. (ed.) 1954. The papers of Thomas Jefferson, vol.10. Princeton, NJ: Princeton University Press.

Breck, Samuel 1843. Historical sketch of Continental paper money. Philadelphia: John C. Clark.

Brock, Leslie V. 1975. The currency of the American colonies, 1700-1764. New York: Arno.

Bullock, Charles J. 1985. The finances of the United States from 1775 to 1789. Madison, WI: University of Wisconsin Press. 1990. Essays on the monetary history of the United States. New York: Macmillan.

Bush, Bernard (ed.) 1980. Laws of the royal colony of New Jersey, 1746-1760. Trenton, NJ: New Jersey State Library, Bureau of Archives and History.

1982. Laws of the royal colony of New Jersey, 1760-1769. Trenton, NJ: New Jersey State Library, Bureau of Archives and History.

1986. Laws of the royal colony of New Jersey, 1770-1775. Trenton, NJ: Division of Archives and Records Management, New Jersey Department of State.

Calomiris, Charles W. 1988. 'Institutional failure, monetary scarcity, and the depreciation of the Continental', Journal of Economic History 48: 47-68.

Carter, Susan B., et al. (eds.) 2006. Historical statistics of the United States earliest times to the present millennial edition, volumes 1 and 5. New York: Cambridge University Press.

Cushing, John D. (ed.) 1981. The first laws of the state of Delaware, vol. 2, part 1. Wilmington, 
DE: Michael Glazier, State Printer of Delaware.

Davis, Andrew McFarland 1964. Colonial currency reprints, 1682-1751, vols. 1-4. New York: Augustus M. Kelley.

Elliot, Jonathan 1843. 'Funding system of the United States and Great Britain', House of Representatives Document No. 15 (Vol. II. Executive Documents), $28^{\text {th }}$ Congress, $1^{\text {st }}$ Session, Read on Dec. 16, 1843.

Farrand, Max (ed.) 1966. The records of the Federal Convention of 1787, vols. 1-4. New Haven CT: Yale University Press.

Ferguson, E. James 1953. 'Currency finance: an interpretation of colonial monetary practices', William and Mary Quarterly Third Series, 10: 153-80.

1961. The power of the purse. Chapel Hill, NC: University of North Carolina Press.

et al. (eds.) 1973-1995. The papers of Robert Morris, 1781-1784, vols. 1-8. Pittsburgh, PA: University of Pittsburgh Press.

Fisher, Edgar Jacob 1911. New Jersey as a royal province, 1738 to 1776. New York: Columbia University, Longman, Green \& Co.

Fortescue, John William 1910-1930. History of the British army. London: Macmillan.

Fowler, William M. Jr. 2011. American crisis: George Washington and the dangerous two years after Yorktown, 1781-1783. New York: Walker \& Company.

Grubb, Farley 2006. 'The U.S. Constitution and monetary powers: an analysis of the 1787 Constitutional Convention and the Constitutional transformation of the U.S. monetary system’, Financial History Review 13: 43-71.

2008. 'The Continental dollar: how much was really issued?' Journal of Economic History 68: 283-91.

2011. 'The distribution of Congressional spending during the American revolution, 17751780: the problem of geographic balance', in Stephen Conway and Rafael Torres Sánchez, eds., The spending of the states-military expenditure during the long eighteenth century: patterns, organisations, and consequences, 1650-1815. Saabrücken, Germany: VDM Verlag Dr. Müller GmbH \& Co. KG: 257-84.

2012a. 'State redemption of the Continental dollar, 1779-90', William and Mary Quarterly Third Series, 69: 147-80.

2012b, 'Is paper money just paper money? Experimentation and local variation in the fiat paper monies issued by the colonial governments of British North America, 1690-1775: 
part I’, NBER working paper \#17997, http://www.nber.org/papers/w17997.

2012c, 'Chronic specie scarcity and efficient barter: the problem of maintaining an outside money supply in British colonial America’, NBER working paper \#18099, http://www.nber.org/papers/w18099.

Harlow, Ralph Volney 1929. ‘Aspects of revolutionary finance, 1775-1783’, American Historical Review 35: 46-68.

Hening, W. W. (ed.) 1969. The statutes at large: being a collection of all the laws of Virginia, vols. 9 and 13. Charlottesville, VA: University Press of Virginia [original 1821, 1823].

Hepburn, A. Barton 1967. A history of currency in the United States. New York: Augustus M. Kelly [original revised \& enlarged edition 1924].

Holton, Woody 2007. Unruly Americans and the origins of the Constitution. New York: Hill and Wang.

Homer, Sidney and Sylla, Richard 1991. A history of interest rates. New Brunswick, NJ: Rutgers University Press, third edition.

Journals of the Continental Congress, 1774-1789, vols. 1-34. [JCC hereafter] 1904-1937. Washington D.C.: Government Printing Office.

Kemmerer, Donald L. 1940. Path to freedom: the struggle for self-Government in colonial New Jersey, 1703-1776. Princeton, NJ: Princeton University Press.

1956. 'A history of paper money in colonial New Jersey, 1668-1775', Proceedings of the New Jersey Historical Society 74: 107-44.

Labaree, Leonard W. (ed.) 1967-1970. The papers of Benjamin Franklin, vols. 11-14. New Haven, CT: Yale University Press.

Laws of the state of Delaware. 1797. Newcastle, DE.

Lester, Richard A. 1938. 'Currency issues to overcome depressions in Delaware, New Jersey, New York and Maryland, 1715-37’, Journal of Political Economy 46: 324-75.

Lint, Gregg L. (ed.) 1996. Papers of John Adams, vol. 9. Cambridge, MA: The Belknap Press of Harvard University Press.

McCusker, John J. 1978. Money and exchange in Europe and America, 1600-1775. Chapel Hill, NC: University of North Carolina Press.

Mevers, Frank C. (ed.) 1979. Papers of Josiah Bartlett. Hanover, NH: University Press of New England. 
Nettels, Curtis Putnam 1934. The money supply of the American colonies before 1720. Madison, WI: University of Wisconsin Press.

Newman, Eric P. 1997. The early paper money of America. Iola, WI: Krause Publications, fourth edition.

Oberg, Barbara B. (ed.) 1992-1998. The papers of Benjamin Franklin, vols. 29-34. New Haven, CT: Yale University Press.

Papers of the Continental Congress, 1774-1789. [PCC hereafter] Washington DC: National Archives Microfilm Publication, M247.

Perkins, Edwin J. 1994. American public finance and financial services, 1700-1815. Columbus, $\mathrm{OH}$ : Ohio State University Press.

Phillips, Henry Jr. 1866. Continental paper money: historical sketches of American paper currency, second series. Roxbury, MA: W. Elliot Woodward.

Puls, Mark 2008. Henry Knox, visionary general of the American Revolution. New York: Palgrave Macmillan.

Rabushka, Alvin 2008. Taxation in colonial America. Princeton, NJ: Princeton University Press.

Ratchford, U. B. 1941. American state debts. Durham, NC: Duke University Press.

Sargent, Thomas J. 2012. 'United States then, Europe now', https://files.nyu.edu/ts43/public/research/Sargent_Sweden_final.pdf [accessed 8 February 2013], Nobel Prize Lecture delivered 8 December 2011, Stockholm, Sweden.

Sherwood, Joseph 1851. 'Letters of Joseph Sherwood [agent for New Jersey in Britain, 17611766]', Proceedings of the New Jersey Historical Society, First Series, 5: 147.

Smith, Adam 1937. The wealth of nations. New York: Modern Library.

Smith, Paul H. 1976-1994. Letters of delegates to Congress, 1774-1789, vols. 1-21. Washington, DC: Library of Congress.

Smyth, Albert Henry 1907. The writings of Benjamin Franklin, vol. 9. London: Macmillan.

Statutes at large of Pennsylvania, vols. 9-10. 1903-1904. Harrisburg, PA: W.M. Stanley Ray, State Printer of Pennsylvania.

Sumner, William Graham 1968. The financier and the finances of the American Revolution, vols. 1-2. New York: Augustus M. Kelly [original 1891].

Syrett, Harold C., and Cooke, Jacob E., eds., 1963. The papers of Alexander Hamilton, vol. 7. New York: Columbia University Press. 
Telser, Lester G. 1995. ‘Optimal denominations for coins and currency’, Economics Letters 49: 425-7.

United States Congress 1834-1856. The debates and proceedings in Congress of the United States, vols. 1-18. Washington DC: Gales \& Seaton.

United States Continental Congress s.n. 1775. Philadelphia?: http://memory.loc.gov/service/rbc/bdsdcc/00301/0001.jpg [accessed 30 January 2013].

Van Hove, Leo 2001. 'Optimal denominations for coins and bank notes: in defense of the principle of least effort', Journal of Money, Credit and Banking 33: 1015-21.

Webster, Pelatiah 1969. Political essays on the nature and operation of money, public finances and other subjects. New York: Burt Franklin [original 1791].

Williamson, John 1796. A treatise of military finance. London: Oxford University. 